|| ISSN(online): 2589-8698 || ISSN(print): 2589-868X ||

International Journal of Medical and Biomedical Studies

Available Online at www.ijmbs.info

NLM (National Library of Medicine ID: 101738825)

Index Copernicus Value 2019: 79.34

Review Article

Volume 5, Issue 3; March: 2021; Page No. 143-162

\title{
REVIEWING MAJOR MICROBES AS A SINGLE CELL PROTEIN
}

\author{
Bharat Kwatra $^{1}$, Prachi Yadav ${ }^{2}$, Shravan Balasubramaniam ${ }^{3}$, Stuti Garg ${ }^{4}$, Tanishka Koyande ${ }^{5}$ \\ ${ }^{1}$ Invenzion Labs Inc \\ ${ }^{2}$ Amity Institute of Biotechnology, Amity University, Delhi \\ ${ }^{3}$ Manipal Institute of Technology, MAHE, Karnataka \\ ${ }^{4}$ Jaypee Institute of Information Technology, Noida \\ ${ }^{5}$ Lokmanya Tilak Municipal Medical College and General Hospital, Maharashtra University of Health Sciences, Mumbai
}

Article Info: Received 10 February 2021; Accepted 22 March 2021

DOI: https://doi.org/10.32553/ijmbs.v5i3.1842

Corresponding author: Bharat Kwatra

Conflict of interest: No conflict of interest.

\begin{abstract}
This article is an examination of reviewing major microbes as a single cell protein (SCP). The scientific development and subsequent analysis of the potential of commonly found microorganisms to be used as a source of proteins in the form of single cell proteins. continues to influence the researchers all over the globe today. This article examines the research done and published by researchers and scientists. Consideration of current trends and data in scientific queries and demonstrates further aspects of Reviewing Major Microbes as a Single Cell Protein. Additionally, this article explores options for Rhodobacter capsulatus, Lactobacillus acidophilus, Saccharomyces cerevisiae, Saccharomyces boulardii, Spirulina, Chlorella, Trichoderma and Polysporous and their potential to produce single cell proteins from waste products such as wastewater, fruit peels and fermentation waste products. This single cell protein can be used for reducing inflammation, combating hyperlipidaemia and showing anti-viral effects.
\end{abstract}

Keywords: Chlorella, Polyporous, Lactobacillus, Saccharomyces, Single cell protein (SCP), waste

\section{INTRODUCTION:}

Proteins are considered as building blocks of the body and also serve as a source of energy. Certain foodstuffs such as lean meat, dairy products, sprouts and eggs, to name a few, are considered to be good sources of protein. Sometimes, individuals do not get get the required amount of protein $(0.8 \mathrm{~g}$ per $\mathrm{kg}$ of body weight). Reasons for Hypoproteinaemia include: Protein Losing Enteropathy (PLE), in which a person loses about $60 \%$ of the total protein serum, excessive workouts, malnutrition, kidneys or liver dysfunction and inflammatory bowel disease.

Globally, $8 \%$ of the population suffers from muscle wasting, according to a survey carried out in 2013. This occurs due to poor diets, poverty and unsanitary living conditions. This can to some extent be tackled by using protein supplements. The most commonly know protein supplements are the Whey powders, but when taken in excess they can cause dysregulated bowel movements and nausea amongst other symptoms. Scientists developed a new kind of carefully measure supplement, a Single cell Protein (SCP).

Single-Cell Protein (SCP) is a protein that is obtained from the cells of microorganisms such as bacteria, protozoa, algae, yeast and fungi. SCPs can be used as a supplement for humans or as feed for animals. Single cell proteins are advantageous as they constitute microorganisms which multiply rapidly thus giving rise to biomass in a short duration of time. Additionally, the microorganisms can be modified such that to produce a protein with a higher nutritional value. Previously, reviews have focused on how microorganisms can be used to produce a single cell protein. This review focusses on how Single Cell Proteins can be produced from waste products using different genera of microorganisms such as bacteria, fungi and algae. These single cell proteins in turn can be used to treat a number of diseases, thus, their potential has to be studied in depth.

\section{METHODS:}

This study was conducted using four databases: Google Scholar, SAGE, DOAJ and PubMed. Selection of papers was done based on keywords and theme relevant to this review. Further, the published papers from these databases were arranged in systemic order with respect to year of publication.

\section{RESULTS AND DISCUSSION:}


3.1 Rhodobacter capsulatus and Lactobacillus acidophilus ${ }^{1-9}$

\begin{tabular}{|c|c|c|}
\hline Sr. No. & Title of Paper & Year published \\
\hline 1 & $\begin{array}{l}\text { Amino acid profiles and presumptive nutritional assessment of single-cell protein from certain } \\
\text { lactobacilli }\end{array}$ & 1977 \\
\hline 2 & $\begin{array}{l}\text { Production of Single Cell Protein in } \quad \text { Stickwater } \quad \text { by } \\
\text { acidophilus and Aspergillus niger }\end{array}$ & 2012 \\
\hline 4 & $\begin{array}{lccccc}\text { Biomass } & \text { recovery } & \text { during } & \text { municipal } & \text { wastewater treatment } & \text { using } \\
\text { photosynthetic bacteria and prospect of production of single cell protein for feedstuff } & \end{array}$ & 2016 \\
\hline 5 & $\begin{array}{l}\text { Current Status on Single Cell Protein (SCP) Production from Photosynthetic Purple Non- } \\
\text { Sulphur Bacteria }\end{array}$ & 2017 \\
\hline 8 & $\begin{array}{l}\text { Single cell protein production from waste biomass: comparison of various industrial by- } \\
\text { products }\end{array}$ & 2018 \\
\hline 9 & $\begin{array}{l}\text { Application of purple phototrophic bacteria in a biofilm photobioreactor for single cell protein } \\
\text { production: Biofilm vs suspended growth }\end{array}$ & 2020 \\
\hline
\end{tabular}
Amino acid profile and nutritional assessment of Single-
cell protein from Lactobacillus acidophilus

The amino acid profiles, modified essential amino acid (MEAA) indexes, and in vitro pepsin digestibility were determined for single-cell protein (SCP) from Lactobacillus acidophilus. SCP from Lactobacillus acidophilus had high MEAA indexes. The essential amino acid compositions of SCP from Lactobacillus acidophilus are comparable to Food and Agriculture organization reference protein and SCP from other sources. The study focussed on the determination of the amino acid composition of SCP from Lactobacillus acidophilus and obtain an assessment of the nutritional value of SCP from this organism and determine the modified essential amino acid indexes and percent digestibility of crude protein. Amino acid compositionLysine is present in higher concentrations in animal protein sources such as beef and egg. The lysine concentration in SCP from Lactobacillus acidophilus surpassed that of beef or whole egg. Invitro pepsin digestibility and MEAA indexThe amino acid concentrations present in a protein source might not have any relationship to the biological activity of the amino acids. Hence a preliminary assessment of the nutritional value of SCP from Lactobacillus acidophilus and the MEAA index as well as in vitro pepsin digestibility were determined. The SCP from Lactobacillus acidophilus had an MEAA index of 86. Lactobacilli are commonly used in industry for the production of fermented food. The lactobacilli SCP in the fermented foods generally constitute only a small percentage of the total protein. Hence it would be desirable to use a strain of Lactobacillus that has a higher quality SCP than a strain of poorer quality SCP. In this study, it was evident that the higher quality strain is Lactobacillus acidophilus.

Single-cell protein production in Stickwater by Lactobacillus acidophilus

The study's aim focused on the investigation of the production of single-cell protein (SCP) using Lactobacillus acidophilus in stickwater from fishmeal factories. Substrate for Lactobacillus acidophilus was stickwater and was compared with the standard medium as control. Maximum chemical oxygen demand reduction by Lactobacillus acidophilus was achieved at a temperature of 55.4C at 74.1 and $97.7 \%$ in the control treatment and stickwater respectively. Maximum protein was obtained by Lactobacillus acidophilus at 71.13 and $68.37 \%$ for control and stickwater respectively. The amount of RNA obtained for Lactobacillus acidophilus was at 15.27 and $15.04 \%$ for control and stickwater respectively. Maximum and minimum amounts of glutamic acid and methionine were obtained through substitution of stickwater and control treatment in both cultures. The results of this study show that the substitution of stickwater as a carbon source allows the production of SCP. The chemical score of SCP in the biomass of Lactobacillus acidophilus in stickwater fulfills adult human nutritional requirements where lysine, methionine, and phenylalanine are the most limiting amino acids. Biomass production and COD reduction using Lactobacillus acidophilus: 
(a)

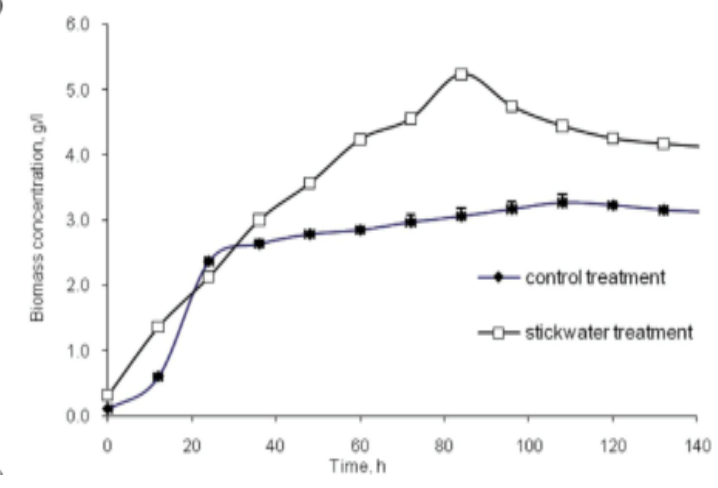

1

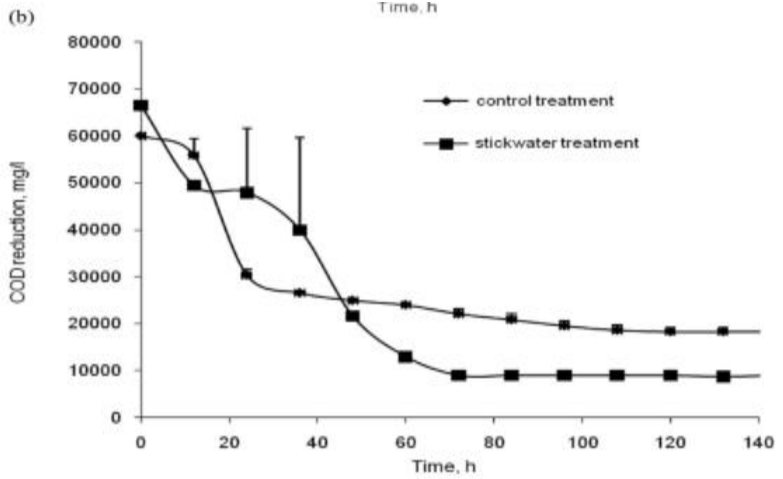

2

Figure 1: Effect of stickwater composition on biomass production and COD reduction using Lactobacillus acidophilus.

The highest amount of biomass production using Lactobacillus acidophilus in the control treatment and stickwater was 3.16 and $5.20 \mathrm{~g} / \mathrm{L}$, respectively, as shown in (1). Similarly, the corresponding COD reduction was found to be 86.55 and $85.6 \%$, as shown in (2). Stickwater had a significant effect on the biomass production and COD reduction for Lactobacillus acidophilus. In general, the protein content in the production of the single-cell for protein should be ideally between 39 to $73 \%$, with the nucleic content of $1-11 \%$. Results of this study had shown that the percentage of protein and RNA in the biomass produced by Lactobacillus acidophilus on stickwater treatment was a little lower than the biomass produced in the control treatment. The aspartic, serine, phenylalanine, and lysine amino acids produced by Lactobacillus acidophilus biomass showed a significant amount of difference between those produced by control and stickwater treatments. The maximum and minimum number of amino acids produced by Lactobacillus acidophilus biomass in the control treatment were glutamic acid and methionine which with the treatment of stickwater were 9.33 and $2.03 \%$, respectively.

The amount of crude protein of Lactobacillus acidophilus biomass grown on stickwater wastewater in this study is comparable to and the highest among the amounts in many corresponding microorganisms reported in the literature. The chemical scores in biomass of Lactobacillus acidophilus in comparison with WHO reference protein are given below. The chemical score provides an estimate of the nutritive value of a protein. This parameter compares levels of essential amino acids between the test as well as standard proteins. The study clearly indicates that Lactobacillus acidophilus can be successfully used for the production of single-celled protein using the substrate stickwater. Sustainable SCP production was observed as the biomass concentration of the bacterial biomass by Lactobacillus was low with a faster bacterial growth and a lower COD reduction, thus ideally making it more suitable for high protein production

\section{Species Characterization of Lactobacillus acidophilus} and application in food production

Lactobacillus acidophilus, a widely known LAB is a grampositive microorganism with a rod morphology of 2-10uM size. It is a group A homofermentative aerobic microorganism that uses glycolysis or EMP pathway for fermentation of hexoses to produce $\mathrm{D}$ and $\mathrm{L}$ amino acids while those present in heterofermentative groups would use phosphoketolase pathway for fermentation of hexoses and pentoses. Lactobacillus acidophilus is a thermophilic strain that shows growth at a temperature of $30-45 \mathrm{C}$ and considerably good growth at $4-5 \mathrm{pH}$. Lactobacillus acidophilus has been isolated from various fermented products like yogurt. Based on the physiological properties it is found that Lactobacillus acidophilus allows maximum production of lactic acid, some acetic acid without hydrogen and catalase. This study research emphasizes on the use of Lactobacillus acidophilus probiotic supplements with great health benefits. Literature study explains the production of SCP from probiotics. The strain Lactobacillus acidophilus was tested for lactic acid production from lactose and it was observed that it can convert $23 \%$ lactose into lactic acid.

\section{Prospect of production of SCP for feedstuff using photosynthetic bacteria}

This study utilizes photosynthetic bacteria for the production of biomass for economical single-cell protein production. Single-cell protein is very common for human consumption as well as animal feed as they have been a high demand for protein supplements on account of the shortage of proteins from plant and animals. Photosynthetic bacteria would be widely used for SCP production as they contain considerably large amounts of biological cofactors, amino acids, and fatty acids. This study aims to determine the protein content and amino acid composition of the biomass produced by photosynthetic bacteria like Rhodobacter capsulatus. 

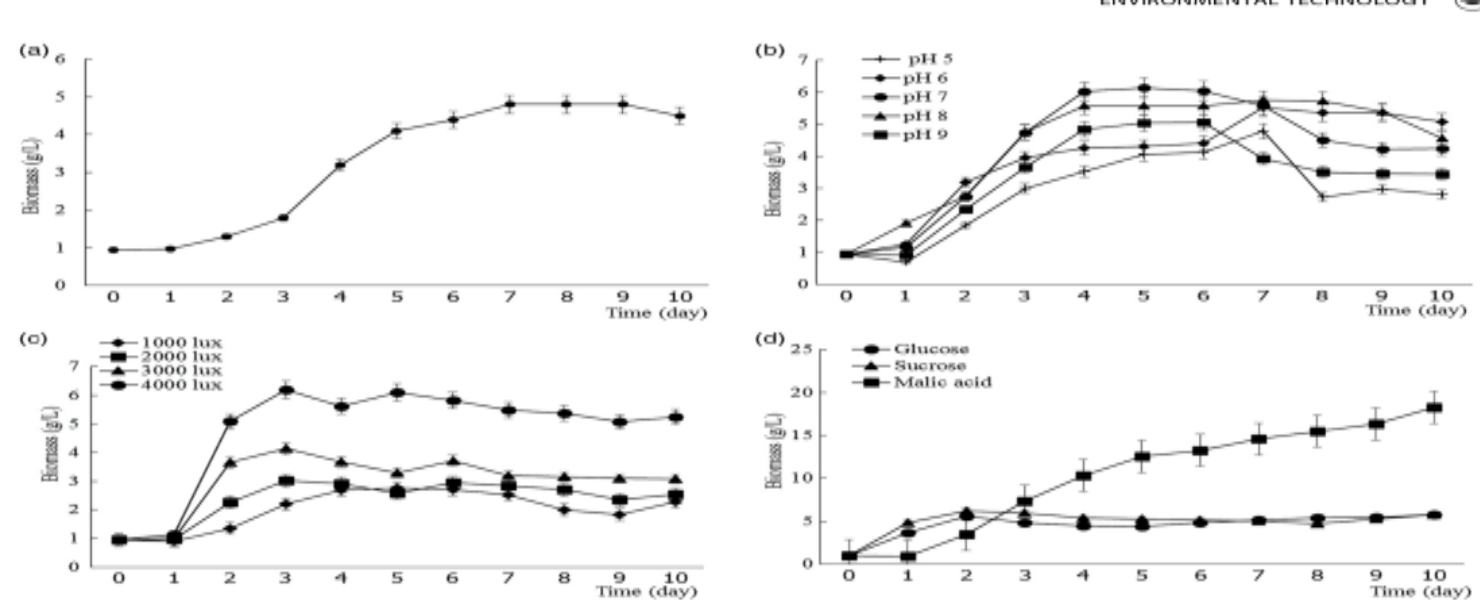

Figure 2: Growth of PPB in undiluted municipal wastewater.

The strain grown in wastewater shows that bacterial growth increases gradually with time and stabilizes. This study reveals that protein-rich biomass can be produced from the municipal treatment of wastewater. Photosynthetic bacteria like Rhodobacter species grown in wastewater under specific conditions were optimal for biomass production.

Single cell protein production from Photosynthetic purple non sulphur bacteria Rhodobacter capsulatus Current status

Single cell protein is the total protein extracted from bacterial cultures. Photosynthetic non sulphur bacteria biomass finds application from fish feeding as it is rich in proteins. This study aims to show that single cell production abilities of PNSB show that Rhodobacter capsulatus would be best in terms of single cell production. 5\% SCP from Rhodobacter capsulatus was reported from cultivation through a synthetic medium.

\begin{tabular}{|l|l|l|l|l|}
\hline $\begin{array}{l}\text { Rhodobacter } \\
\text { capsulatus }\end{array}$ & $\begin{array}{l}\text { Synthetic medium } \\
\text { Lasum }\end{array}$ & Remediation & $\begin{array}{l}\text { Alexandre, } \\
\text { (2009) }\end{array}$ \\
\hline
\end{tabular}

In-depth analysis shows that purple bacteria Rhodobacter capsulatus was ideal for single-cell protein production.

Production of SCP from agricultural wastewater using purple phototropic bacteria

SCP is available commercially, from heterotrophic bacteria and is used as animal feed in aquaculture. It was however observed that the production costs of SCP would have to decrease to compete with agricultural alternatives. Contextually industrial wastewater may be of interest as a substrate for the production of SCP as carbon and other nutrients have a negative value in wastewater. At the same time, the combination of the production of SCP and treatment of wastewater can balance both operating and capital costs of the wastewater treatment plant. The main SCP mediator includes purple phototropic bacteria like Rhodobacter capsulatus. Photoheterotrophic growth for purple phototropic bacteria could be exploited with high COD: N:P uptake ratios and high yields on account of energy utilization from infra-red light. This study focuses on the study of the SCP yield and composition from a mixed culture of PPB like Rhodobacter capsulatus. For every batch PPB inoculum was analyzed for physicochemical as well as microbial composition using analytical methods. The biomass of purple phototropic bacteria formed in the tests had high crude protein content. The analysis of the microbe in the initial and final samples collected from the PPB tests showed a dominance of PPB throughout the test especially Rhodobacter capsulatus (32\%). PPB like Rhodobacter capsulatus is efficient in terms of the ability to produce SCP product in phototropic material.

\section{Production of single cell production from biomass waste} - Review of agriculture byproducts

Single cell proteins are referred to as dietary single-celled microorganisms whose biomass or protein extracts are derived from a pure or mixed microscopic bacterial culture. These can be used as protein-rich food or ingredients for food or dietary supplements. It is essential to use biodegradable agro-industrial by-products a a source of nutrients to reduce the cost of SCP production as well as the cultivation of microorganisms. This paper focuses on protein-rich wastewater like stickwater. Stickwater is a liquid by-product from the production of fish feed production. It is quite evident that stickwater as a substrate could provide high protein concentrations in a microbial biomass

\begin{tabular}{|llll|}
\hline $\begin{array}{l}\text { Protein or lipid rich } \\
\text { sources }\end{array}$ & Microorganisms & $\begin{array}{l}\text { Protein } \\
\text { content (\%) }\end{array}$ & References \\
\hline Stickwater & Aspergillus niger & 48.7 & Kam et al., 2012 \\
& Lactobacillus acidophilus & 68.4 & \\
\hline
\end{tabular}

This review focussed on the advantages and disadvantages of using stickwater as a substrate of Lactobacillus acidophilus for SCP production.

\section{Production of single-cell protein from waste biomass}

Waste from industries accounts for a considerable amount of manmade waste streams of which would cause harm to the environment if it is untreated. Hence conversion of these wastes to valuable products would provide appreciable 
recycling efforts to be more economically viable. An example would be a single cell protein that can be derived from various waste materials through microbial fermentation. SCP is a microorganism biomass or protein extract derived from microscopic algae, yeast, fungi, or bacterial culture, which could be used in animal as well as human nutrition This review focuses on various biodegradable byproducts as substrates for SCP production. The table below lists the industrial wastes applicable for SCP production for Rhodobacter capsulatus. Waste gases are a unique source of nutrients.

Figure: These are the results obtained from the study

\begin{tabular}{|c|c|c|c|}
\hline \multicolumn{4}{|c|}{ Table 1. Industrial wastes applicable for SCP production. Recent reports of protein content ( $\%$ of biomass after fermentation } \\
\hline Polymer-rich sources & Microorganisms & Protein content, \% & Ref. \\
\hline Waste paper & Scyaliditum acidophilum & 47 & [18] \\
\hline \multirow[t]{3}{*}{ Sulfite waste liquor } & Paecilonyces variotil & 55 & \multirow{2}{*}{ [35] } \\
\hline & Fusarium venenatum & 55 & \\
\hline & Candida utilis & . & [20] \\
\hline Lignin residues & Chrsonilia sitophila & 39.2 & [40] \\
\hline Latex rubber sheet wastewater & Rhodopseudomonas palustris & 65 & [47] \\
\hline \multicolumn{4}{|l|}{ Carbon compounds } \\
\hline \multirow[t]{2}{*}{ Methane } & Mehtylomonas sp. & 69.3 & [56] \\
\hline & Bacteria isolated from soil & 71 & [53] \\
\hline \multirow[t]{2}{*}{ Methanol } & Melhylophilus methylotrophus & . & [86] \\
\hline & Pichia pastoris & 35 & [87] \\
\hline \multirow{3}{*}{$\begin{array}{l}\text { Formic acid } \\
\text { Waste gases }\end{array}$} & Bacteria isolated from soil & 71 & [53] \\
\hline & Mehylococcus capsulatus & . & [69] \\
\hline & Rhodobacter capsulatus & . & [70] \\
\hline
\end{tabular}

It was found that carbon compounds, especially waste gases, have the greatest potential in becoming widely used carbon sources for various types of microbial fermentations for SCP production, but further advancements in these technologies are required for these sources to become more widely accepted.

\section{Single cell protein production for a purple phototropic bacterium in a biofilm photobioreactor.}

This study aims to determine the application of phototropic purple bacteria (PPB) like Rhodobacter capsulatus on the infrared irradiated, submerged surface for SCP production. It was found that more than $60 \%$ of the total biomass was grown as a biofilm with the rest being suspended. The biomass was harvested around 160g TSL-1 along with high protein $(>96 \mathrm{gL}-1)$ and low ash content. Substrates for SCP production include food-processing effluents such as dairy, beverage, brewery, and possibly other effluents. Suspended mixed purple phototropic bacteria cultures have also been applied for poultry, red meat, and sugar processing wastewater treatment. The study answers the questions of what fraction of the total biomass was incorporated into the biofilm, what was the biofilm composition and is it suitable as a single cell protein product. Microbial community- The mainly identified PPB genera included Rhodobacter capsulatus. Microbial analysis of the attached and suspended biomass in the biofilm photobioreactor confirmed the presence of PPB up to $77 \%$ and $56 \%$ of relative abundance in biofilm as well as the reactor liquid. PBR can generate PPB biomass with high protein content on complex wastewater with a considerable fraction of feed COD to the recovered biofilm. The advantages of the biofilm are high crude protein and amino acid contents, harvestability and up-concentration as well as product consistency. In terms of undesired components such as metals, the biofilm had generally lower average contents compared to the suspended fraction but accumulated zinc and aluminium. Biosorption of these components has been reported for Rhodobacter capsulatus.

\subsection{Saccharomyces cerevisiae, Saccharomyces boulardii and Aspergillus niger ${ }^{10-19}$}

\begin{tabular}{|l|l|l|}
\hline $\begin{array}{l}\text { Sr. } \\
\text { No. }\end{array}$ & Title of Paper & $\begin{array}{l}\text { Year } \\
\text { Published }\end{array}$ \\
\hline 1 & Single cell protein production by Aspergilus niger and its evaluation & 1991 \\
\hline 2 & Studies on production of single cell protein by Aspergillus niger in solid state fermentation of rice bran & 2001 \\
\hline 3 & Production of Single Cell Protein from Saccharomyces cerevisiae by utilizing Fruit Wastes & 2010 \\
\hline 4 & Production of Single Cell Protein from Orange Peels Using Aspergillus niger and Saccharomyces cerevisiae & 2014 \\
\hline 5 & Single Cell Protein production: A Review & 2015 \\
\hline 6 & $\begin{array}{l}\text { Production of Single Cell Protein from Fruit of Beles (Opuntia Ficus-Indica L.) Peels Using Saccharomyces } \\
\text { cerevisiae }\end{array}$ & 2015 \\
\hline 7 & $\begin{array}{l}\text { Single Cell Protein Production by Saccharomyces cerevisiae Using an Optimized Culture Medium Composition in } \\
\text { a Batch Submerged Bioprocess }\end{array}$ & 2016 \\
\hline 8 & $\begin{array}{l}\text { Production of single cell protein (SCP) from food and agricultural waste by using Saccharomyces cerevisiae } \\
2017\end{array}$ & 2019 \\
\hline 9 & $\begin{array}{l}\text { Valorization of Pineapple Peels through Single Cell Protein Production Using Saccharomyces cerevisiae NCDC } \\
364\end{array}$ & Prospective production of fructose and single cell protein from date palm waste \\
\hline 10
\end{tabular}




\section{Using Aspergillus niger production of single cell protein from alkali treated corn cobs}

With the increasing population in the world the demand for the food with full of proteins is also increasing. So, cellulose is the most promising substrate for the production of single cell protein (SCP). Single cell protein can help in reducing the demand of the food. There are many studies based on this purpose. In this study we will talk about production of SCP from Corn cobs by the fermentation as they are highly rich in cellulose. In this experiment Aspergillus niger was isolated in the media containing alkali treated corn cobs and amino acid analysis was carried out in Beckman model. And in the results, it was seen that SCP product was obtained which composed of all essential amino acids and fatty acids and it was also seen that SCP had $77 \%$ in vitro dry matter digestibility and it was a good supplement as the feed component. In this experiment first Aspergillus niger was isolated from the decomposed substrates and grown in basal media containing alkali treated corn cobs as it was the carbon source. Then the culture broth was filtered in Whatman No.1 filter paper after incubating for 6 days at 28$30^{\circ} \mathrm{C}$ on a rotary shaker. Then crude protein and true protein was measured using Kjeldahl method and method of LOWRY respectively after making the biomass dried at $65^{\circ} \mathrm{C}$ in the oven. And Crude fat and ash contents were determined according to AOAC. And amino acid analysing was carried out by Beckman model. And then Tryptophane content was determined calorimetrically. After performing the experiment, it was observed that biomass decreased continuously for 6 days and after that it remained constant. SCP product content $30.4 \%$ crude protein, $26.7 \%$ true protein. Crude protein is high due to the nitrogen from the sources such as nucleic acids and amines. A well product of SCP was formed with the help of Aspergillus niger and corn cobs which was alkali treated. And according to the recommendation of Protein Advisory Group of United Nations $4 \mathrm{~g}$ of daily intake of nucleic acids are safe for most of the adults and with the help of SCP $2 \mathrm{~g}$ of nucleic acids can be taken. The microbial protein provides a great source for the protein for ruminants as well as monogastric animals. After evaluation the protein quality and amino acid composition in terms of IVDMD indicates SCP is well suitable as a protein feed supplement. Hence, we can say that SCP product which obtained after the fermentation process with alkali treated corn cobs by Aspergillus niger was contain all essential components such as all essential amino acids and fatty acids.

Production of single cell protein in solid state fermentation bran by rice using Aspergillus niger

For increasing population manufacturing of protein supplements become necessary. For this purpose, single cell protein (SCP) production is becoming more evident. In this study, an experiment was conducted with solid state fermentation (SSF). SSF is a process of manufacturing biomolecule used in the food, pharmaceutical, fuel and textile industry. In this method fungi show best growth due to its low water activity and presence of intractable solid substrate. So proper growth of fungi in SSF gives higher yield of biomass. And Mycelial tips of fungi have immense turgor pressure which helps in penetrating the hard substance. Biggest advantage of this method was it does not require any prearrangements for media preparation. In this experiment Aspergillus niger were isolated and then total protein were extracted to estimate the mycelial biomass from the moldy bran. Then using various sources of nitrogen and mineral solution was compared for the final biomass yield. So, ratio 1.387 of $\mathrm{C} / \mathrm{N}$ was resulted to be more effective for nitrogen supplements as this ratio gives higher biomass yield._In this experiment a local Aspergillus niger was required from decaying wood in the soil and culture was maintained on PDA slants at $28 \pm 2^{\circ} \mathrm{C}$. Oil free rice bran was used to remove lignin. and then bran was dried to obtain 50-mesh size and made ready to for SSF process. For protein extraction different buffers were used from Aspergillus niger. Different mineral solution and nitrogen sources were prepared. The nitrogen solution was prepared by adding $0.05 \mathrm{~g}$ of the compound i.e., sodium nitrate, ammonium nitrate and ammonium sulphate and $10 \mathrm{ml}$ of distilled water respectively. Three flasks were prepared and inoculated with $2 \mathrm{ml}$ of spore suspension of Aspergillus niger. For mixing the spore suspension flask were tapped gently. All these flasks were incubated at $28 \pm 2^{\circ} \mathrm{C}$ for eight days. Then homogenization of the flask takes place with the help of carbonate- bicarbonate buffer. For estimating total sugars $1 \mathrm{~g}$ of substrate was added in $60 \mathrm{ml}$ of distilled water and kept at an ambient temperature for $12 \mathrm{hrs}$ for the extraction of sugars as soaking makes the bran softer. The biomass was expressed in terms of total protein content. As a result, it was seen that ice bran showed higher carbon content after pre-treatment with alkali (carbon content $=$ $3.458 \mathrm{mg} / \mathrm{g}$ of rice bran). The protein yield with different buffers came as citrate buffer 3.403; phosphate buffer 6.351; carbonate-bicarbonate 6.884 and sodium hydroxide $(0.1 \mathrm{~N})$ 3.154. And $\mathrm{C} / \mathrm{N}$ ratio came as the $\mathrm{C} / \mathrm{N}$ for pre-treated rice bran was 1.729. The highest biomass yield was obtained when the $\mathrm{C} / \mathrm{N}$ was 1.387 . The high biomass yield was also observed for $\mathrm{C} / \mathrm{N} 1.729$ when mineral solution supplemented the medium. From this result it can clearly say that nitrogen availability is the major factor for controlling final biomass yield. And can also say that $\mathrm{C} / \mathrm{N}$ ratio was not more effective for controlling the biomass yield as compared to supplementation of rice bran with various nitrogen sources or mineral solution separately or in combination improved the Aspergillus niger growth.

\section{Using Fruit waste For the Production Single Cell Protein from Saccharomyces cerevisiae}

For developed and developing countries there are basically two reasons for producing single cell protein (SCP). The first basic reason is the majority of the people are live below poverty line so they are the people who are suffering from malnourishment. So, they required immediate action for taking balanced and nutritive diet. So balanced diet with full of nourished food can be accomplished by intaking single cell protein. Second reason is the disposal of the fruit and vegetables waste. So, the residues can be used as for the production of affordable cheap substrates for culturing 
fungal species which can be harvested as a source of SCP which can be used as human and animal supplement. So, if the waste is utilized systematically and regularly it can used for production of SCP. Production of SCP is the only appropriate method for fulfilling the gap between requirements and supply of proteins. For this purpose, a comparative study was done between residues of banana, mango, sweet orange, pomegranate and apple and the results revealed that banana skin generates highest amount of protein per $100 \mathrm{~g}$ of substrate used. Thus, fruit and vegetable wastes should be exploited properly as a substrate for the production of cellular biomass of edible or food fungi instead of dumping them on roads, in the drains and water bodies.The present investigation was done for the comparative study which used for the production of single cell protein using Saccharomyces cerevisiae grown on different fruits wastes. For this experiment required some beakers, test tubes, conical flasks all were properly washed and sterilized. Residues were of the banana, pomegranate, mango, sweet orange, and apple. The material was washed with the help of tap water and then autoclaved at $121^{\circ} \mathrm{C}$ and 15 Psi pressure for 45 minutes in beakers and conical flask. Then sterilized material inoculated with Saccharomyces cerevisiae. Then inoculated plate kept into incubator at $27 \pm$ $2^{\circ} \mathrm{C}$. observation took place from $2^{\text {nd }}$ day for cellular growth. After cellular growth thick layer was removed and transferred into Whatman filter paper no.1. The filter papers containing the biomass were dried at $90 \pm 2 \mathrm{oC}$ for 24 hours to get moisture free fungal contents. The fungal biomass was estimated for the protein contents by Kjeldahl method. After study the results said that banana skin has highest amount of protein as compared to other.

\section{A review on the production of single cell protein using Saccharomyces cerevisiae from orange peel}

In India people are facing majorly two problems, first, a greater number of people suffering from malnutrition and the second is increasing pollution. These problems can be resolved by converting agro- industrial waste into highly nutrient food such as single cell protein (SCP). As protein is the backbone of the human being. Proteins are necessary for every step of growth in the life. It carries out different biochemical reactions in the form of enzyme. Compare to any other macromolecules, our body required protein in abundant. Single cell protein are the dead cells of microorganism like yeast, bacteria, fungi and algae. This technique is very popular among contemporary world at commercial level. For this purpose, an experiment was conducted with orange peels. Orange peels were inoculated with Saccharomyces cerevisiae in a batch method. Three separated batches were kept under observation. And e S. cerevisiae biomass was obtained by submerged fermentation. Then The fungal biomass of each batch was analysed for its ash, crude fibre, crude fat and protein contents. In this experiment orange peels were taken of three types Citrus aurantium, Citrus sinensis and Citrus paradisi. After collection dust particles were removed by washing with distilled water. Then with the help of electric grinder crushed fine powder was formed. S. cerevisiae were obtained from Microbial Type Culture Collections. The peels were treated with $30 \% \mathrm{HCl}$ and were kept in water bath at $75^{\circ} \mathrm{C}$ for one hour to obtain monosaccharides. Then orange peels were inoculated with Saccharomyces cerevisiae in three batches and each batch observed separately. Time duration of first batch was for 8 days at $32^{\circ}$ C. second for 6 days at $30^{\circ} \mathrm{C}$ third for 4 days at $28^{\circ} \mathrm{C}$. then these cells were transferred to aluminum foil with the help of filter paper to remove all moisture content. As a result, the protein content of three batches were in $1^{\text {st }}$ batch The $\mathrm{C}$. aurantium showed highest protein content $(13.37 \%)$ while in rest of the citrus peels the protein contents were recorded as 11.9 and $11.53 \%$ for C. paradisi and C. sinensis, respectively. In batch $2^{\text {nd }}$ it was recorded as $20.37 \%$ (C. paradisi), $18.68 \%$ (C. sinensis) and $18.0 \%$ (C. aurantium). And in batch $3^{\text {rd }}$ it was recorded as; $21.06,20.62$ and $17.75 \%$ for C. paradisi, C. sinensis and C. aurantium, respectively.

\section{A Review on Single Cell Protein Production}

Population increasing day- by- day not only in India but as worldwide. Problem of food sources is also increasing rapidly. In particularly, if we see problem of deficiency of protein is major. It can be solved with the technology of production of single cell protein (SCP). SCP is dried cells of microorganisms such as algae, fungi. Bacteria, yeast and many more. It can be used as animal feeds or human food. It has many advantages such as with high amount of protein content it also contains fats, carbohydrates, nucleic acids, vitamins and minerals, and also rich in certain amino acids. Both conventional and non- conventional substrates can be used for the production of SCP. Conventional such as starch. Fruit, and vegetables wastes and non- conventional are petroleum by-products, natural gas, ethanol, methanol and lignocellulosic biomass. Many researches have been carried out and as a result it came out that many natural products can be used for the production of SCP such as dates extract, cashew, apple juice. In one investigation it was resulted that cellulose and hemicellulose waste can be used as a substrate. One investigation talks about that using $\mathrm{S}$. cerevisiae with banana skin provides best results for production of SCP as compare with pomegranate, apple waste, mango waste and sweet orange peel. And also came to know that highest amount amount of biomass yield gram of substrate was obtained from Aspergillus niger when grown on banana extract supplemented with basal media (16\%). Producing SCP form any microorganism has both advantages and disadvantages. Such as producing with bacteria, Bacteria has rapid growth, short doubling time but obtaining SCP from bacteria has high nucleic acid content which may cause kidney stone and also has high risk of contamination during the process.

\section{Study on production of single cell protein using Saccharomyces cerevisiae from fruit of beles}

With the growing population day by day the demand of protein rich food is also increasing. So, in this study we were try to overcome the problem by producing single cell protein (SCP) from fruit of beles using Saccharomyces 
cerevisiae. SCP production is one of the major steps for this goal. SCP is the protein derived from microorganisms such as algae, bacteria, yeast, mold, and fungi. And among this yeast is the most widely accepted or can say most used microorganism for this purpose. For this an experiment was conducted with fruit of beles which used for the production of SCP using Saccharomyces cerevisiae by submerged fermentation. Beles also called as cactus pear it is common in northern Ethiopia. As a result, beles fruit peels generate $51.1 \%$ and $27 \%$ crude carbohydrate and crude protein, respectively per $100 \mathrm{gm}$ of substrate used. And Percentage of protein in single cell protein was lower it was just $32.5 \%$. And when Saccharomyces cerevisiae grown the percentage of protein increased to $63.5 \%$._After collection of cactus or peels of beles fruit they were washed with distilled water and then converted into dry fine powder with the help of electric grinder. Then the peels were fermented with Saccharomyces cerevisiae and the culture was maintained on slant of potato dextrose agar medium and stored at $4{ }^{0} \mathrm{C}$. after this the sample preparation $\mathrm{S}$. cerevisiae have been done by treating the peels with $50 \mathrm{ml}$ of $10 \% \mathrm{w} / \mathrm{v} \mathrm{HCl}$ and kept in a water bath at $75{ }^{\circ} \mathrm{C}$ for one hour to obtain monosaccharides as $\mathrm{S}$. cerevisiae lacks the enzymes responsible to hydrolyse the polysaccharides into simpler glucose units. And then sterile solution was used as carbon and nitrogen source for biomass production. Now, SCP production and harvesting occur by submerged fermentation which carried out in three trials in Erlenmeyer flasks. In first trail, supplemented Beles' fruit peels hydrolysate medium is SBFPHM for second GSBFPHM and for third BFPHM. After sterilization at $121^{\circ} \mathrm{C}$ for 15 minutes inoculums of $2 \mathrm{ml}$ from suspension of Saccharomyces cerevisiae was aseptically transferred into each medium. After fermentation which was carried out for 6 days the biomass was separated from culture broth by vacuum filtration and washed with sterile water. And then weighing of biomass takes place by transferring into aluminium disk dried in the oven for $1 \mathrm{hr}$. After study the results came out as the medium GSBFPH has highest percentage of carbohydrate $63.5 \%$ and medium BFPHM shows lowest percentage of protein $53.4 \%$. But In contrast, protein content in fermented biomass was much lower (27.5\% only) in Supplemented Beles' fruit peels Hydrolysates (SBFPH) compared to that of in Beles' fruit peels Hydrolysates Medium (BFPHM). So, it is concluded as the study shows fruit of beles peel extracted different ingredients such as ash content which shows it has organic compound also has fibre content which is needed for growth of the microorganism and crude fat, carbohydrates.

\section{Using optimized culture medium composition for the production of single cell protein in a submerged bioprocess by Saccharomyces cerevisiae}

With the increase in population in the world the protein demand is also increasing across the world. So, limited amount of protein leads to the discovery of Single cell protein (SCP). It is known for good enrichment factor. It's one of the biggest advantages is its production process just involves the conversion of waste material into value added foods which helps in reducing environmental pollution.
Saccharomyces cerevisiae is well known for the production of single cell protein as it has fermentative capabilities to utilize sucrose, glucose, fructose, and maltose as carbon sources. In this study S. cerevisiae growth, reproduction, and its ability for SCP was evaluated in batch submerged culture. A fraction of full factorial methodology and Qualitek-4 software were applied to determine an optimal culture medium composition led to the highest cell biomass production and protein content yield. In the result it was observed that Produced cell numbers and protein content of dry biomass using optimal culture medium were considerably higher than those in some other microbial species. S. cerevisiae PTCC5269 was prepared as lyophilized strain. And then some slant was prepared of S. cerevisiae on Plate Count Agar medium and stored at $-20^{\circ}$ C. For preparing yeast suspension opalescent colonies of $\mathrm{S}$. cerevisiae were transferred from the Petri plate surface to 5$\mathrm{mL}$ sterile distilled water using a heated loop after 48-h incubation at $35^{\circ} \mathrm{C}$. For the production of SCP 32 separate shake flasks were used. Each shake flask was contained fixed amounts of potassium di-phosphate, magnesium sulphate, manganese sulphate, and zinc sulphate, each one at a concentration of $1 \mathrm{~g} \mathrm{~L}-1$. For preparation of culture medium all the components were weighted and dissolved in distilled water and then were strolled in autoclave at $120^{\circ} \mathrm{C}$ for $15 \mathrm{~min}$. for the cell production of $\mathrm{S}$. cerevisiae $100-\mathrm{mL}$ sterile culture medium was added to each $250-\mathrm{mL}$ shake flasks. Then all the flasks were kept for incubation. After measurement of all the components using a spectrophotometer at a wavelength of $600 \mathrm{~nm}$ biomass of $\mathrm{S}$. cerevisiae which was filtered and centrifuged used for determination of protein content in cell biomass after drying at $65^{\circ} \mathrm{C}$ for about $30 \mathrm{~h}$ until reach to constant weight. In the result maximum yeast cell number were obtained in $2^{\text {nd }}$ flask in which concentration was as ammonium sulphate, iron sulphate, glycine, and glucose concentrations adjusted on $0.3,0.05,1$, and $50 \mathrm{~g} \mathrm{~L}-1$, respectively. And minimum was observed in $7^{\text {th }}$ flask in which components concentration were as ammonium sulphate, iron sulphate, glycine, and glucose concentrations adjusted on $0.4,0.1,2$, and $40 \mathrm{~g} \mathrm{~L}-1$, respectively. So, in a conclusion we can say that Due to high obtained protein content in dry cell biomass of S. cerevisiae PTCC5269, there is good potential to commercial this process.

\section{Utilising food waste for the production of Single cell protein using yeast (Saccharomyces cerevisiae)}

Now- a- days food waste is the biggest problem for the health of the people. Food waste can be utilised for the production of by- products such as single cell protein. Most of the studies showed that fruit waste has been used for the animal feed. In the study using organic food waste was investigated for producing microbiological culture broth for obtaining single cell protein and from this large amount of protein additives can be produced. Many studies also shows that yeast is most useful microorganism used for this purpose as it has many advantages such as larger size and consist of high quantity of nucleic acids. The main purpose of this study was producing single cell protein from the 
mixture of food waste using Saccharomyces cerevisiae was carried out by fermentation test. In this experiment used 251 automatic Bio stat $\mathrm{E}$ reactor out of which 151 volume has been used. The test was conducted to observe the ability of yeast of using fruit waste as substrate without using pretreatments such as chemical or thermal. _ Initially the percentage of protein in the single cell protein is $15.3 \%$ and then finally reached to $39.8 \%$. In the starting the percentage of protein was less but as the fermentation process increases the small increments were observed in different matrices. The increment in the protein takes place due to the growth of the microorganism. The supernatant total nitrogen values remain almost constant during the entire fermentation process except for the samples from $7^{\text {th }}$ to $11^{\text {th }}$ day of fermentation in this period there was a slightly decrease. This study shows the possibility of production of single cell protein utilising food waste with no pre-treatments required. Now more further studies will be on the co- fermentation of waste food. Microorganism which considers as single cell protein are very useful as protein additives and then they became the important source of biomolecules. The reuse of food waste for feed production is an extensively investigated research area, for both health purposes and the bio-based economy developing

\section{Production of Single Cell Protein from Pineapple Peels using Saccharomyces cerevisiae}

Increasing population across the world causes starvation and protein deficiency. So, for overcome these problems the people need to find some alternative. For this single cell protein was one of major discovery. Use of SCP as food additive increase the possibility of converting agro- waste into protein production. SCP is dead cells of microorganism among which yeast is widely used as yeast is composed of high protein content and low nucleic acid content. And as food supplement yeast is easily digestible and non- toxic. The SCP contains all major molecules such as carbohydrates, fats, nucleic acids, vitamins and minerals. And it also contents some essential amino acids such as lysine and methionine which majorly missing in all plants and animals. Producing SCP is very flexible it can be produce using waste substrate. This study involves using fermentation method production of single cell protein from high carbohydrate pineapple peels using Saccharomyces cerevisiae. In this study used an acid hydrolysis method for releasing fermentable sugars from pineapple peels and replacing complex media components with simple hydrolysates. And in this high- performance thin-layer chromatography also used for deducing essential amino acids. And as result this technique revealed that tryptophan included a comparatively higher concentration of $6.52 \%$, followed by threonine $(3.25 \%)$. It was also observed that Saccharomyces cerevisiae produced SCP in pineapple peelbased media as compared to non- optimised media. Different components were purchased from different area such as discarded pineapple peels were collected from local fruit market of Coimbatore. Lactose, dextrose, maltose, starch, sucrose, peptone, sodium nitrate, ammonium acetate, ammonium sulphate, agar, yeast extract and beef extract.
Then strain was prepared by sub-culturing in yeast extract peptone agar including $0.3 \% \mathrm{w} / \mathrm{v}$ of yeast extract, $1.0 \% \mathrm{w} / \mathrm{v}$ of peptone, $2.0 \% \mathrm{w} / \mathrm{v}$ of dextrose, $2.0 \% \mathrm{w} / \mathrm{v}$ of agar and 100 $\mathrm{ml}$ of distilled water. Now, collected pineapple were washed with distilled water to remove dirt. For substrate preparation $8 \mathrm{~g}$ of fine powder required which was stored in air-tight container and sterilized at $121^{\circ} \mathrm{C}$ for $20 \mathrm{mins}$. Then the mixture of substrate and distilled water of volume $200 \mathrm{ml}$ was filtered using cheese cloth and acid hydrolysis using $\mathrm{HCl}$. Now SCP production takes place by S. cerevisiae was inoculated into $10 \mathrm{ml}$ of yeast extract and then incubated in shaker incubator for $24 \mathrm{hrs}$ at $150 \mathrm{rpm}$ at $25^{\circ} \mathrm{C}$. For the fermentation two different media were used for the study Media 1 Basal medium included basal media components and Media 2 included PPH based media and the basal media components without glucose. For optimization one factor at a time approach was used as $100 \mathrm{ml} \mathrm{PPH}$ were used instead of distilled water. In the observation it was observed that the highest biomass and protein contents were achieved in Peel Hydrolysate Media. And in amino acid profiling it was observed that Tryptophan was comparatively higher concentration of $6.52 \%$, followed by threonine $(3.25 \%)$. Other EAAs were found in relatively lower concentrations.

\section{Production of single cell protein using date palm waste from Saccharomyces cerevisiae}

World widely the half of the production of dates is wasted and remain unutilized. So, dates are the best raw material which can be used for the production of single cell protein. As dates are very nutritious it carries Protein: 2 grams, Potassium: $20 \%$ of the RDI, Magnesium: $14 \%$ of the RDI, Copper: $18 \%$ of the RDI, Manganese: $15 \%$ of the RDI. Single cell protein is dead cell of microorganism such bacteria, yeast. Fungi and many more. SCP is used as animal and human fodder, biocatalyst in medical industry, and aroma and vitamin carrier. Among this yeast is the widely accepted microorganism as it has high protein content, rapid growth rate, no pathogenicity, fast digestibility and palatability. In this study the Saccharomyces cerevisiae was fermented for the extraction of date for the production of single cell protein and then the effect of air flow and $\mathrm{pH}$ were evaluated. The result came out to be cell mass production was obtained in the range $\mathrm{pH}$ of 5.0-5.6, while less cell mass was obtained at $\mathrm{pH}$ less than 5. cell mass increased from 0.6 to $9.0 \mathrm{~g} / \mathrm{L}$. The yeast growth in controlled $\mathrm{pH}$ was inhibited. In this investigation the Saccharomyces cerevisiae was based on ATCC (American Type Culture Collection) procedure. The incubation of the yeast was conducted in agar slant at $30^{\circ} \mathrm{C}$ for 5 days in an incubator. Then for propagation liquid medium was prepared which consist of $10 \mathrm{~g}$ dextrose, $10 \mathrm{~g}$ yeast extract, $3.5 \mathrm{~g}$ peptone, $2 \mathrm{~g}$ KH2PO4, $1 \mathrm{~g} \mathrm{MgSO} 4.7 \mathrm{H} 2 \mathrm{O}, 1 \mathrm{~g}$ (NH4)2SO4, $1 \mathrm{~g} \mathrm{FeSO} 4.7 \mathrm{H} 2 \mathrm{O}$ and de-ionized water. Then add the culture with $100 \mathrm{ml}$ of liquid medium to a $500 \mathrm{ml}$ flask and then shaken into a rotary incubator for propagation at $30^{\circ} \mathrm{C}$ and $120 \mathrm{rpm}$ for $36 \mathrm{~h}$ this way the preparation of microorganism and media takes place. Now, preparation of substrate occurs the extraction of dates was done by deionized water at $50^{\circ} \mathrm{C}$ for $2 \mathrm{~h}$ with 0.4 weight ratio of 
dates to water. Then the sugar syrup was obtained by centrifuging the suspended solids and fibres. Then fermentation process began which consist of $90 \%$ substrate and $10 \%$ liquid medium. The fermentation process was conducted at $33^{\circ} \mathrm{C}$ and agitation speeds $160 \mathrm{rpm}$. Various air flows were used at $\mathrm{pH} 5.3$ such as $0.1,0.5,0.75,1,1.25$ and $1.5 \mathrm{vvm}$. For analysis one millilitre sample was taken from the beginning of the fermentation to 7 days. The sample was put into the Eppendorf and centrifuged at 15,000 rpm for 6 min to separate the cell mass. Then the cell mass was dried at $80^{\circ} \mathrm{C}$ over night. The results were came out to be the increase in cell mass in the initial $24 \mathrm{hrs}$ was about 1.5 times higher as compared to after $24 \mathrm{hr}$. The maximum cell mass yield was at $\mathrm{pH} 5.6$ and final $\mathrm{pH}$ reach to 4 and it was $0.225 \mathrm{~g} / \mathrm{g}$.

\subsection{Spirulina and Chlorella ${ }^{20-31}$}

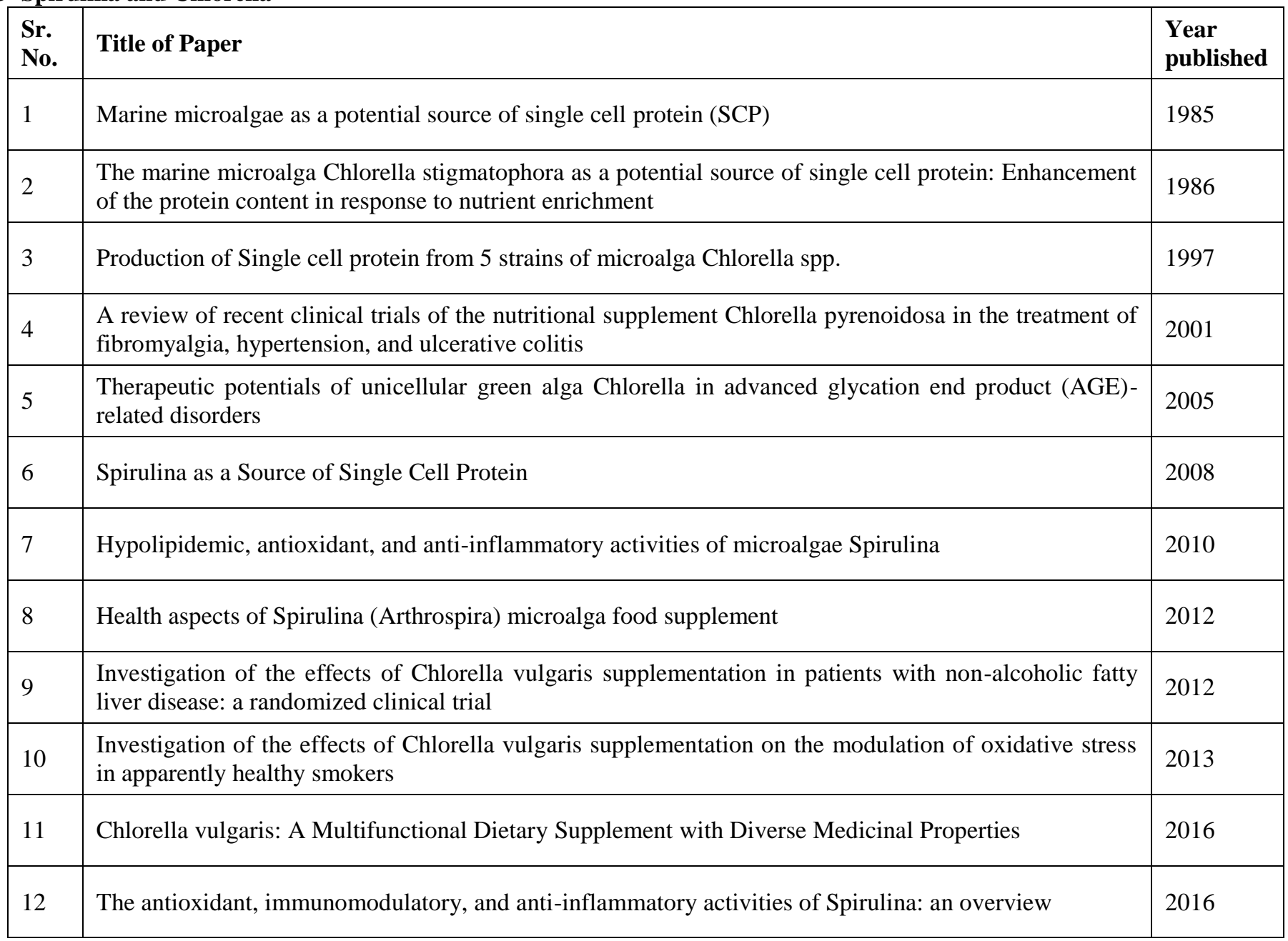

Evaluation of the protein content with emphasis on the essential amino acid composition of marine microalga Chlorella stigmatophora

The protein content of $C$. stigmatophora was analysed to find its Modified Essential Amino Acid (MEAA) index. According to the figures projected in this study, it can be used as a source of single cell protein. The microalga was analysed to evaluate its protein content. The MEAA index was determined. It reflected the values of various essential amino acids excluding tryptophan as it was destroyed during acid hydrolysis. $C$. stigmatophora with MEAA index of 84.98 which followed the MEAA index of Spirulina (85.22) which was the highest amongst the microalgae compared. Available lysine value of $C$. stigmatophora was higher than
Spirulina. But it was noted that the methionine and cystine contents were low.

The content of individual essential amino acids was remarkably high in $C$. stigmatophora and Spirulina. In conclusion, $C$. stigmatophora and Spirulina both hold a potential of being utilized as a single cell protein

Differential culturing of marine microalga Chlorella stigmatophora to evaluate its growth response in and potential as a single cell protein

C. stigmatophora was cultured in batches of varying nutrient concentration to retrieve the highest possible protein concentration. According to the resultant figures of this study, it was evident that $C$. stigmatophora was a viable source of single cell protein. 
The conditions of the culture were altered to allow maximum production of biomass. After several trials the nutrient concentration to provide maximum cellular density was determined to be eight $\mathrm{mM}$ of $\mathrm{NaNO}_{3}$. This study had extensive data collection including various combinations of parameters and their close monitoring. Analysis of raw data indicated that production of this marine microalga was enhanced by the alteration of culture media. The growth velocity and the biomass produced were amplified along with the increase in protein content. The optimum nutrient concentration was derived from these trials. Correlations between the growth of biomass in various phases of the growth curve were visualized. This study portrayed that $C$. stigmatophora was an efficient source of single cell protein and its protein content could be maximized under optimum parameters.

Evaluation of the five strains of microalga Chlorella spp. in various conditions to find their potential as a source of single cell protein

Five strains of Chlorella species (M109, M121, M122, M138, M150) which were extracted from various habitats, were evaluated and studied under different environmental conditions. Seven factors had an affirmative effect on the protein content of the five strains. Only sodium chloride had a negative effect on strain M150. The abstract concluded that production of single cell protein from the five strains of Chlorella was regulated by changing various environmental factors which were mentioned above. Maximum of optimization was performed to increase the biomass and single cell protein production.

Assessment of the therapeutic potential of Chlorella pyrenoidosa against fibromyalgia, hypertension, and ulcerative colitis

C. pyrenoidosa, a green alga which had a high concentration of proteins, vitamins and minerals. This study utilised it as a nutritional supplement in people with diseases like fibromyalgia, hypertension, and ulcerative colitis. Positive results were seen indicating therapeutic potential of $C$. pyrenoidosa against fibromyalgia, hypertension, and ulcerative colitis.

The clinical trials were conducted amongst 55 subjects with fibromyalgia, 33 with hypertension, and nine with ulcerative colitis. Subjects consumed ten $g$ of pure chlorella in tablet form and $100 \mathrm{~mL}$ of a liquid containing an extract of chlorella each day for two or three months. [i] Various parameters were checked in these subjects to confirm the effects of the supplementation: a) For fibromyalgia subjects: pain evaluation and overall quality of life. b) For hypertensive subjects: sitting diastolic blood pressure and serum lipid levels. c) For subjects with ulcerative colitis: determination of state of disease using the Disease Activity Index. [ii] Results were conclusive of decrement in high blood pressure, reduction of cholesterol levels, enhanced wound healing capacity and immune function. $C$. pyrenoidosa has the capacity to improve the body functions of patients with fibromyalgia, hypertension, or ulcerative colitis.

\section{Use of Chlorella in the treatment of advanced glycation end product related disorders}

The non-enzymatic reaction between reducing sugars and amino groups of proteins leads to the formation of Amadori products. These were the products of early glycation, which had undergone further complex reactions to form advanced glycation end products (AGE). AGE caused many diseases like diabetes, atherosclerosis, diabetic microangiopathy and ageing. Advanced glycation end product receptor interaction was seen in neurodegenerative diseases, melanoma growth, expansion and metastasis. This portrayed that inhibition of AGE could be used as a therapeutic intervention for AGE related disorders. Chlorella had shown evident counteraction AGE in vitro. This opened up the possibility of putting this organism in therapeutic use. It had a potential to be used in the treatment of various AGE-related disorders. Therapeutic uses in AGE related disorders: AGE reacted with their respective surface receptors and expressed an inflammatory response. Hence, they played an evident role in the etiopathology of diabetes and associated diabetic vascular complications like diabetic atherosclerosis. It was noted that AGE played an important part in the advancement of malignant melanomas and neurodegenerative disorders like Alzheimer's disease. This indicated that the blockade of AGE had a great potential in the treatment of the abovementioned disorders. Chlorella showed the possibility of fulfilling these therapeutic needs. Anti-oxidative, antiinflammatory and anti-tumour properties: Chlorella elicited anti-oxidative, anti-inflammatory and anti-tumour properties in vitro. This research paper showed that Chlorella had great potential in the treatment of AGE related disorders. But so far, the clinical trials had only shown positive effects in vitro. The scope of this paper could be expanded by supplementing this literature along with clinical trials held in vivo. Moreover, various other questions needed further research, like, mechanism of action of Chlorella against AGE, how effective it proved to be against serious diseases like atherosclerosis, neurodegenerative diseases inside the human body, was there any severe side effect that could trigger other disease conditions. This paper added that Chlorella had anti-oxidative, anti-inflammatory and antitumor properties in vitro. It was important to collect substantial clinical evidence for the same.

\section{Spirulina: Therapeutic and nutritional uses}

This article focused on the various therapeutic uses of Spirulina along with its nutritional value as a single cell protein. Spirulina was not just a rich source of various nutrients but also had various other therapeutic uses which had been put to use in the field of medicine.

Immunostimulatory effect: Immulina which was an immunostimulatory polysaccharide had been isolated from Spirulina. It lacked a cellulose cell wall hence it was easier to digest and could be given to patients who had gastrointestinal problems. It helped in immune system 
modulation by enhancing the cytotoxicity of natural killer cells. Source of nutrition: Spirulina had high content of leucine, valine and isoleucine which were essential amino acids. Weight loss and cholesterol control: After consumption of Spirulina for four weeks in a regulated amount, significant weight loss and reduction of cholesterol was seen. Studies showed that body weight and cholesterol levels were reduced. Cholesterol levels were reduced by the action of Gamma Linolenic Acid present in Spirulina. Other clinical and biochemical parameters remained unaltered. Anticancer action: Beta carotene was isolated from this organism. Beta carotene was effective against free radicals that changed normal cells into cancerous cells. A study conducted in hamsters affected by oral cancer, showed a significant reduction in the tumour on application of beta carotene solution extracted from Spirulina. The Spirulina extracts were capable of stimulating Tumour Necrosis Factor which promoted death of tumour cells. Antiviral action: Calcium-Spirulan, extracted from Spirulina, showed significant antiviral activity against various dangerous viruses. Antimicrobial action: Spirulina maxima had counteraction against various microbes like Bacillus subtilis, Streptococcus aureus, Saccharomyces cerevisiae, and Candida albicans. Acrylic acid was present in high quantities which provided anti-microbial activity. Owing to the rich nutrient content, Spirulina portrayed the potential of treating a multitude of diseases and deficiencies. Clinical trials in some cases need to be more profoundly conducted before using the extracts in their full potential in case of anti-cancerous uses. Certain extracts like Immulina and Calcium Spirulan had already been tested and put to fullfledged use, giving the organism more credibility for enhanced research. It was not just a source of single cell protein but more importantly contains essential amino acids which had made it a better single cell protein than other cyanobacteria. No side effects were observed due to the consumption of Spirulina as a nutritional supplement. The protein efficiency ratio was high. It had been mentioned that it had anti-arthritic, anti-inflammatory and anti-oxidative properties too, but this needed to be researched further.

\section{Evaluation of the uses of Spirulina against hyperlipidemia, oxidative stress and inflammation}

Spirulina was found to be a rich source of single cell protein. Various studies claimed that it also had hypolipidemic, antioxidant and anti-inflammatory properties. Most trials indicated a positive result and supported the above-mentioned properties of Spirulina. But it was noted that these results were only seen in preclinical trials and there was a need for further investigation before using this organism in humans. Hypolipidemic effect: Various experiments and clinical trials on animal models had shown that Spirulina was able to increase the levels of high-density lipoprotein (HDL) which had a protective effect against cardiovascular diseases. A study conducted among 30 male subjects with mild hyperlipidaemia or hypertension. They were divided into two groups; one group received $4.2 \mathrm{~g}$ of Spirulina daily for eight weeks whereas the other group was given Spirulina for four weeks, followed by regular food for another four weeks. [i] After eight weeks reduced levels of total serum cholesterol were seen. When the supplementation was discontinued for four weeks, cholesterol levels increased back to the baseline level which was seen before the supplementation. It was noted that there were no changes in body weight and serum triglycerides. No serious side effects were seen. Various such clinical trials were conducted, all had similar conclusions. Antioxidant and anti-inflammatory effects: Oxidative stress and inflammation caused development of various diseases. Any antioxidant and anti-inflammatory agent could be used in treatment of these diseases. Spirulina supplementation favoured the action of antioxidant enzymes like glutathione peroxidase, oxidized glutathione reductase and seleniumdependent glutathione peroxidase. In a study, 26 female subjects were given Spirulina supplements of $7.5 \mathrm{mg} /$ day for eight weeks significantly decreased serum IL-6 levels and IL-6 produced from peripheral blood lymphocytes, this demonstrated the anti-inflammatory activity of Spirulina. [ii] Another double-blind and placebo-controlled study was conducted with 78 healthy elderly subjects, supplementation of Spirulina at a dose of eight g/day for 16 weeks resulted in a significant rise in plasma interleukin (IL)-2 concentrations in both male and female subjects with a concurrent reduction in IL-6 concentration in male subjects, and an increased superoxide dismutase activity in female subjects. [iii] Safety profile: After conducting various trials on animal models, it was established that there are no serious side effects of consumption of Spirulina. Spirulina showed hypolipidemic effects. Phycocyanin is a component of Spirulina which showed evident reduction in serum total cholesterol and atherogenic index but it elevated the levels of HDL cholesterol. But advanced studies need to be conducted to confirm these findings. The antioxidant and anti-inflammatory effects of this organism were due to two active contents phycocyanin and $\beta$-carotene. Phycocyanin had the ability to scavenge free radicals, including alkoxy, hydroxyl, and peroxyl radicals. It reduced nitrite production, suppressed inducible nitric oxide synthase expression, and inhibited liver microsomal lipid peroxidation. [iv] In a study to compare $\beta$-carotene, vitamin $\mathrm{E}$, and nitric oxide as membrane antioxidants, it was found that $\beta$-carotene protected against singlet oxygen-mediated lipid peroxidation. Studies showed that $\beta$-carotene inhibited the production of nitric oxide and prostaglandin E (2), and suppressed the expression of inducible nitric oxide synthase, COX-2, TNF- $\alpha$, and IL- $1 \beta$. [v] Various preclinical studies supported the antioxidant and anti-inflammatory actions of Spirulina but there were very few clinical trials conducted in humans which demonstrated this.

Therapeutic uses of Spirulina or Arthrospira in immunomodulatory, antiviral effects and in prevention of certain diseases along with its safety factors and side effects.

The objective of this article was to explain the role of Spirulina in immunomodulation and in antiviral effects against Human Immunodeficiency Virus (HIV) along with its safety aspects and side effects. It also included the 
clinical potential of phycocyanobilin, a constituent of Spirulina. Spirulina showed significant stimulation of immunomodulation in subjects of both sexes. It was a better nutritional supplement than soybean, which was concluded by notable weight increase and improvement of hematological parameters in HIV infected adults and in HIV negative undernourished children. Phycocyanobilin, present in Spirulina was an important source for preventing various diseases which involved the excessive activity of NADP oxidase enzyme. Due to its chemical composition, Spirulina possessed significant therapeutic benefits (immunomodulation and antiviral effects). It had certain side effects in a narrow range of subjects (headache, stomach ache, muscle pain, flushing of the face, sweating and concentration difficulties). Arthrospira platensis and Arthrospira maxima had been given Class A safety ratings by the Dietary Supplements Information Expert Committee. The immunomodulatory and antiviral properties of $A$. platensis were seen due to a high molecular weight anionic compound isolated from this microalga. Recently, an acidic polysaccharide fraction had also been isolated from $A$. platensis, which induced the synthesis of TNF- $\alpha$ (Tumour Necrosis Factor) in RAW macrophages. [i] Spirulina was considered to be a rich source of protein containing various other nutrients like Vitamins B1, B2 and B3. It was an important source of Gamma Linolenic Acid (GLA), which was a rare polyunsaturated fatty acid with a high nutritional value. In a clinical trial amongst a group of 40 subjects comprising both sexes and age of 50 years or above, Spirulina supplements (three g per day) were given for 12 weeks. It was observed that the mean corpuscular haemoglobin values were elevated with no gender variations. An increase of indoleamine 2,3-dioxygenase enzyme activity (a sign of immune function) and white blood cell count were observed in the majority of subjects.[ii] Another recent clinical trial that involved two studies, a pilot study with 11 individuals and a double-blind placebo-controlled study with 12 individuals, healthy volunteers supplemented their diet with 200 or $400 \mathrm{mg}$ day1 , respectively, for seven days with Immulina (a commercial extract of A. platensis, which was known to activate THP-1 monocytes and $\mathrm{CD}+\mathrm{T}$ cells in vitro and enhance immunological functions in mice). [iii] Immulina showed improvement of natural killer cell activity. Evidence was presented that Braun-type lipoproteins of the Spirulina commercial extract were responsible for the major portion of the in vitro monocyte activation.[iv] 33 participants volunteered in another study to compare the effect of $A$. platensis and soybean as food supplements on insulinresistant HIV-infected patients. $19 \mathrm{~g}$ of supplement of Spirulina or soybean was given daily for eight weeks. Insulin sensitivity in HIV patients was more for those who received Spirulina supplements than soybean supplements. It was noted that phycocyanobilin extracted from Spirulina has inhibitory effect NADPH oxidase enzyme. This property could be utilised to treat disorders associated with NADPH oxidase overactivity. Clinical trials indicated towards various therapeutic properties of $A$. platensis but it must be noted that more research needed to be conducted in humans in order to evaluate the complete action of Spirulina against viruses and its affirmative effects in immunomodulation. The Food and Drug Administration (FDA) of the USA has categorized several Arthrospira dried biomass products as "generally recognized as safe" (GRAS) for human consumption. [v] It was concluded that Spirulina had no serious side effects in humans. But its supplementation was avoided in patients with autoimmune disorders, phenylketonuria, as they may pose risk of anaphylaxis and other complications. Overall, it was safe for consumption but it may have had mild side effects like headache, stomach ache, muscle pain, flushing of the face, sweating and concentration difficulties.

\section{Evaluating the therapeutic use of Chlorella vulgaris against non-alcoholic fatty liver disease}

Assessing the effects of providing supplements of $C$. vulgaris to patients who had non-alcoholic fatty liver disease (NAFLD). A randomized clinical trial was performed to estimate its therapeutic use. Conclusion: The findings of this trial concluded that $C$. vulgaris had evident effects against NAFLD. The given study was a randomized, open-label clinical trial. It was conducted amongst 76 subjects with NAFLD who were randomly divided into two Groups - Chlorella group and metformin group: Group 1) Chlorella group $(\mathrm{n}=33)$, receiving $C$. vulgaris extract $(1200$ $\mathrm{mg} /$ day $)+$ metformin $(750 \mathrm{mg} /$ day $)+$ vitamin $\mathrm{E}(200$ $\mathrm{mg} /$ day) for three months, and Group 2) Metformin group $(n=43)$, receiving metformin $(1250 \mathrm{mg} /$ day $)+$ vitamin $E$ (200 mg/day) for three months.[i] After this supplementation, various serum and blood parameters were monitored along with weight, body mass index (BMI) and homeostasis model assessment of insulin resistance (HOMA-IR) index. It was noted that weight and BMI had reduced in Group 1) and 2). Serum ALT, AST, triglycerides, uric acid, HbA1c and HOMA-IR index were reduced in the Chlorella group whereas significant changes in total cholesterol, LDL, HDL and FBS were observed in the metformin group. There were borderline significant reductions in insulin and FBS in the Chlorella group.[ii] It can be concluded that $C$. vulgaris had a therapeutic potential in the treatment of NAFLD due to its affirmative effects on serum levels of transaminases, triglycerides as well as insulin sensitivity

\section{Study of antioxidative effects of Chlorella vulgaris supplementation on chronic Iranian smokers}

Smoking caused various cardiovascular and pulmonary disorders. It was proven to be carcinogenic. It caused oxidative stress in the body which in turn led to deteriorating effects. This study was conducted to evaluate the antioxidative properties of the microalgae $C$. vulgaris in the case of Iranian smokers. It was observed that the extracts derived from $C$. vulgaris had antioxidative effects on the subjects of the study. This organism could be used to reduce deaths associated with smoking. Initially the trials began with 40 individuals but two dropped out due to gastrointestinal side effects. In this study $C$. vulgaris showed elevation in serum levels of superoxide dismutase, 
glutathione peroxidase, catalase, vitamin $\mathrm{E}$, vitamin $\mathrm{C}$ and total antioxidant status while decrease in malondialdehyde. It showed that $C$. vulgaris was capable of weakening lipid peroxidation in chronic smokers. Subjects who were given extracts isolated from this microalga showed increased serum antioxidant level along with decreased malondialdehyde levels. A similar pattern of changes was seen in both genders except that females did not have significant change in vitamin E levels. This concluded that C. vulgaris extracts can help in reducing the disease burden and mortality rate associated with smoking. [i]

This study aimed at evaluating the antioxidant properties of C. vulgaris in chronic smokers. It contained a high concentration of micro and macronutrients. It showed great potential in relieving antioxidative stress. But it was noted that it may have had side effects in certain individuals. Although the side effects were not grave, this topic is an area open to further research.

Assessment of the therapeutic potential of Chlorella vulgaris in improvement of hyperlipidaemia and hyperglycaemia, functioning against antioxidative stress, cancer and chronic obstructive pulmonary disease

C. vulgaris, a rich source of protein, had high content of various macro and micro nutrients. It was seen that Chlorella supplementation helped against the abovementioned medical problems via altering molecular mechanisms underlying these effects.

Evaluation of the therapeutic potential of Spirulina against oxidative stress and inflammation along with studying its role in immunomodulation Spirulina had high concentrations of proteins and vitamins. Due to its rich chemical composition, it possessed antioxidant and antiinflammatory properties along with enhancement of immunomodulation. This research paper concluded that Spirulina showed antioxidant, anti-inflammatory and immunomodulatory effects in various trials conducted in animal models, but its efficiency in the human body was a subject of further research.

Antioxidant property: Free radicals or reactive oxygen species were responsible for causing oxidative stress which can progress into various diseases. Several in vitro studies showed that $S$. maxima contains 2 antioxidant enzymes superoxide dismutase (SOD) and catalase (CAT). Clinical trials proved that Spirulina had therapeutic potential in the treatment of diseases associated with overproduction of reactive oxygen species. This property was seen due to the chemical component phycocyanin. It also provided antioxidative action to phycocyanobilin. Phycocyanobilin effectively inhibited the peroxidation of methyl linoleate and the oxidation of phosphatidylcholine liposomes. [i] It was noted that these two components provide protection against diabetic nephropathy by inhibiting oxidative stress. [ii] Immunomodulatory property: Various animal studies showed that Spirulina had immunomodulatory property. They indicated that Spirulina increased Interleukin-1 $\beta$ (IL$1 \beta)$, IL-4, and interferon (IFN)- $\gamma$ production. [iii] A study was conducted in mice having systemic candidiasis and breast cancer. They were given supplements of $S$. platensis in the dosage of $800 \mathrm{mg} / \mathrm{kg}$ of body weight for three days. It was seen that the expression of genes encoding IL-4 and IL10 was significantly reduced, whereas that of genes encoding IL-17, TNF- $\alpha$, and IFN- $\gamma$ was markedly increased. [iv] Spirulina also showed immunomodulation in elderly male and female human subjects. After giving supplements, it was noted that the plasma concentration of IL-2 had increased whereas the plasma concentration of IL-6 had decreased. Anti-inflammatory effect: Phycocyanin had antiinflammatory effects which made Spirulina supplementation, a viable treatment against colitis and arthritis. A study was conducted in mice having arthritis, wherein the subjects were given $100,400 \mathrm{mg} / \mathrm{kg}$ of Spirulina orally for eight days. It was seen that the inflammatory reaction had decreased following this supplementation.

Spirulina had the ability to stimulate cellular antioxidant enzymes, it inhibited lipid peroxidation and DNA damage. It destroyed free radicals and promoted the activity of superoxide dismutase and catalase. This microalga had antiinflammatory and immunomodulatory effects, mechanisms of which were unclear. Spirulina supplements under the dosage of $15 \mathrm{~g}$ per day (or less) was proven to be safe and did not produce any toxic effects. The overall nutritional status of Spirulina was well researched but its therapeutic uses required further investigations.

\subsection{Polyporous and Trichoderma}

\begin{tabular}{|l|l|l|}
\hline $\begin{array}{l}\text { Sr. } \\
\text { No. }\end{array}$ & Title of Paper & $\begin{array}{l}\text { Year } \\
\text { Published }\end{array}$ \\
\hline 1 & $\begin{array}{l}\text { Single-cell protein production by Trichoderma longibrachiatum on treated sugar-cane bagasse. Biotechnology and } \\
\text { Bioengineering }\end{array}$ & 1980 \\
\hline 2 & Lignocellulose biotechnology: current and future prospects. Critical Reviews in Biotechnology \\
\hline 3 & $\begin{array}{l}\text { Single cell protein production by Trichoderma harzianum using waste banana peel. International Journal of Microbiological } \\
\text { Research }\end{array}$ & 2011 \\
\hline 4 & Single cell protein: production and process. American Journal of food technology \\
\hline 5 & Single cell protein and baker's yeast & 2011 \\
\hline 6 & Microorganisms: A marvellous source of Single Cell Proteins \\
\hline 7 & Single Cell Protein: A Review & 2013 \\
\hline 8 & Production of Single cell protein from sugarcane using fungi & 2013 \\
\hline 9 & Production of single cell protein by a local Trichoderma reesei in solid state fermentation: effects of process variables. & 2015 \\
\hline
\end{tabular}


Trichoderma longibrachiatum on treated sugar-cane bagasse used for production of Single cell Protein

During the investigation of the biodegradation of sugar-stick bagasse and the cellulolytic exercises of parasites segregated from it, we found Trichoderma longibrachiatum which gave similar outcomes to Chaetomium cellulolvticum (ATCC 32319 ) in the creation of cellulase and single-cell protein (SCP) $(70 \%$ protein in mycelium) on cadmxymethylcellulose (CMC). Be that as it may, notwithstanding the presence of gelatin $(9.1 \%)$, cellulose (28.3\%), and hemicellulose (36.3\%), sugar-stick bagasse has a $21.2 \%$ lignin content' which makes it immune to microbial assault. Pretreatment of cellulosic squander for expulsion of lignin has been widely utilized by different work-ers.2-6 In the greater part of the investigations lignin as well as hemicellulose was taken out to make cellulose more defenseless to microbial assault. The point of the current examination was to inspect the capability of $T$. longibrachiatum for the creation of SCP utilizing pre-treated sugar-stick bagasse, the last being accessible in enormous amounts as a side-effect of unadulterated sweetener industrial facilities. Between the two kinds of treated bagasse utilized as substrates, holocellulose end up being the best SCP creation by $T$. longibruchiutum. Use of substrate and protein creation were at a similar level as the control on account of doubly treated bagasse (cellulose), while higher on account of independently treated bagasse (holocellulose). In spite of the fact that there was very little contrast in the fmal transformation of treated substrates and cellulose powder, the usage of substrate was a lot faster on account of holocellulose. With the last $27 \%$ protein was created in the item in $144 \mathrm{hr}$. This rate is higher than that revealed for some parasites. However, the level of SCP delivered in the current case was lower than that detailed for Chaetomium cellulovticum on treated wheat straw and sawdust. The better outcomes got with $T$. longibrachiatum on holocellulose may be on the grounds that the bagasse was blessed to receive eliminate the lignin substance just and, in this way, permitting the organic entity to use the more most loved carbon source, i.e., hemicellulose alongside cellulose,' while in the vast majority of the prior the pressure was laid on expulsion of the hemicellulose alongside the lignin. The poor SCP creation on untreated bagasse might be because of the safety of the substrate. Cellulose alone didn't show as high creation of SCP as in blend with hemicellulose maybe in view of less use as substrate by the growth. The most noteworthy cellulolytic action on cellulosic bagasse and control, moderate action on holocellulose, and least on untreated bagasse was subject to the accessibility of the substrate, in this manner showing the versatile idea of cellulase. The high $\mathrm{Cx}$ action alone couldn't give any development on untreated bagasse. From the above apparently there is no reasonable connection between singular catalyst movement and biomass creation or substrate use. Comparative perceptions have been made before.

Current and Future Prospects of Lignocellulose in Biotechnology
Lignocellulose is the most plentiful biomass accessible on Earth. It has pulled in extensive consideration as another feed stock and energy asset on account of the enormous amounts accessible and its inexhaustible nature. The expected employments of lignocelluloses are in mash and paper ventures, creation of fuel liquor and synthetic compounds, protein for food, and feed utilizing biotechnological implies. The current modern action of lignocellulosic biomass aging is restricted basically due to the trouble in monetary bioconversion of these materials to esteem added items. Significant improvement in numerous cycles identified with lignocellulose biotechnology showed up during the most recent decade. Flow employments of lignocellulosic biomass, measure limitations, and regions of future exploration are examined here.

\section{Review Analysis on Trichoderma harzianum used for Single Cell Protein using waste banana peel}

Submersed Fermentation $(\mathrm{SmF})$ was used for the creation of single cell protein (SCP) utilizing banana strip squander as substrate. A neighborhood detaches of Trichoderma harzianum, delivered critical degree of biomass yield within the sight of various carbon and nitrogen sources Sodium nitrate was discovered to be a successful nitrogen enhancing source, as it gave the higher sporulation and biomass yield The most extreme sporulation promotion biomass was seen when medium enhanced with sucrose as carbon source. Supplement found in banana strip extricate were 6.000 5nude protein, 5.10.05 rough fiber, 374003 fat and 57.1002s carbohydrates. The isolated fungal culture acquired from rotting wood in the dirt was connected chiefly to the conventional classification Trichoderma known as Trichoderma harzianum. The after effects of the synthetic investigation of the banana strip extricate was seen. Banana strips which contain variable fixings and these might be utilized as a carbon fuel hotspot for the development of parasites in the creation of single cell protein The impact of various carbon sources on the mycelial dry biomass and protein of 7 . hartiane was recorded.From the outcomes it was uncovered plainly that the $T$, harzianum showed murked selectivity in using diverse carbon sources Among all these carbon sources, the supplementation of banana strip remove with sucrose gave the most noteworthy protein yield Sporulation and biomass yield was additionally greatest in sucrose followed by glucose and maltose Poor development and biomass yield was gotten when enhanced with lace. If there should arise an occurrence of nitrogen sources, the supplementation of bararua strip separate with sodium nitrate gave the most elevated protein yield of $0.78001 \mathrm{u} /$ trailed by $06903 \mathrm{~g}$ when enhanced with ammonium mitrate Banana strip is perhaps the most bountiful and locally accessible horticultural waste which variable fixings sch as carb that $\mathrm{a} b$ ed a carbon and fuel hotspot for the development of parasites in the creation of single move protein 17. 81 The expansion of turient supplements gave accessible nitrogen sourve to for the age consequently enduncing its development.

A review Analysis on Production and process of Single Cell Protein. 
Dried cell of microorganism is called Single Cell Protein which are utilized as protein supplement in human food sources or creature takes care of. Microorganisms like green growth, parasites, yeast and microscopic organisms, use modest feedstock and squanders a wellspring of carbon and energy for development to create biomass, protein concentrate or amino corrosive. Since protein account for the quantitatively significant piece of the microbial cells, these microorganisms, additionally called single cell protein as characteristic protein concentrate. With increment in populace and overall protein lack the utilization of microbial biomass as food and feed is more featured Although single cell protein high nutritive incentive because of higher protein, nutrient, fundamental amino acids and lipid content, there is uncertainty to be supplanted to the ordinary protein sources because of the high spotless substance and more slow in edibility They likewise might be considered as unfamiliar material by body, which may in this way bring about hypersensitive responses. Single cell protein is the dried cell wall of the microorganism which can be used as a source of protein. Due to the rising problem of shortage of protein and nutrients all around the world has given us the alternative option to produce Single cell protein. Many microorganisms such as fungi like Polyporous and Trichoderma.

\section{Detail Review of Single cell protein and Baker's yeast}

Single cell protein commonly alludes to wellspring of blended protein extricated from unadulterated or blended culture of green growth, yeast, parasites or microbes. The microorganisms which are utilized for single cell protein creation should be non-pathogenic to plants, creatures and man. Great healthy benefit, effectively and economically created on scale, poison free, quickly developing, effectively to isolate from the medium and to dry. They have numerous quiet elements. Biomass creation is normally done in nonstop mode to boost yields and monetary scale. The crude material of this interaction is modest in light of the fact that we utilized molasses, whey, gas, oil and so on For a substrate. So, SCP is waste to best. The molasses and different salts including ammonium and phosphate salt contain of the pastry specialist's yeast. The yeast is utilized for the creation of SCP. The cook's yeast is helpful to as and they make hindrances additionally the SCP and dough puncher's yeast valuable for life form. Single cell protein effectively to synthesized in mechanical scale. Crude material of this interaction is extremely modest on the grounds that we utilized a molasses, whey, gels, oil, and so on. For substrate, the dough Baker's yeast is helpful to Single cell protein creation and valuable organic entity. Fungi can also be used for the production of single cell protein .Single cell protein is the dried cell wall of the microorganism which can be used as a source of protein . Due to the rising problem of shortage of protein and nutrients all around the world has given us the alternative option to produce Single cell protein. Many microorganisms such as fungi like Polyporous and Trichoderma.

\section{Source of Single Cell Protein : Microorganism}

The creation of single-cell protein is certainly not a new turn of events. Since 2500 B.C. various microorganisms have been utilized as a piece of the eating regimen in the structure of aged food. Refined dairy items contain 107 to 1010 lactic corrosive microbes for each gram of item. During the first century B.C., eatable mushrooms were widely devoured in Rome. In the sixteenth century blue green growth (Spirulina) was devoured as a significant wellspring of protein. The large-scale manufacturing of miniature creatures as an immediate wellspring of microbial protein was acknowledged during World War-I in Germany, and thus, present day bread cook's yeast (Saccharomyces cerevisiae) was created. In the $1960 \mathrm{~s}$, scientists at British Petroleum built up a "proteins-from-oil measure", an innovation for delivering microbial protein utilizing yeast took care of with waxy n-paraffin, a result of petroleum treatment facilities. The technique had an ability to deliver 10,000 tons of microbial protein per annum. The expression "microbial protein" was supplanted by another term "Single Cell Protein" (SCP) in 1966 by Ditty L. Wilson. Single-cell living beings contain proteins, fats, sugars, debris fixings, water and different components like phosphorus and potassium. The creation relies on the living being and the substrate on which it develops. There are a few regular structures which are contrasted and soya supper and fish dinner. On the off chance that SCP is to be utilized effectively, there are five principal properties that should be fulfilled. It should be protected to eat. It should have a high dietary benefit, especially of amino corrosive. It should be worthy to the overall population. It should have the usefulness, for example qualities, which are found in like manner staple nourishments. It should be financially practical to create. Green growth develops auto-tropically and combine their food by taking energy from daylight or counterfeit light, carbon from carbon dioxide, and supplements from sugars present in the development medium. Chlorella strains are being utilized for an assortment of uses in biotechnology. Because of their high protein content, they serve to improve protein allow and can be utilized as feed for creation of creature protein. Spirulina is another algal SCP which is broadly filled in many created nations, like Japan, the United States, and European Countries. This alga is sold in the market under brand name Spirulina Powder. Mass development of Spirulina has a few points of interest over other alga, like Chlorella and Scenedesmus, and so forth since it is not difficult to develop, less inclined to defilement, simple to collect and simple to process. There are different impediments on SCP which upset it from being utilized for human utilization, despite the way that it is a decent wholesome source. In green growth, the most significant limit is the presence of the algal cell divider. People come up short on the cellulase protein and consequently they can't process the cellulose segment of the algal divider. To be utilized as nourishment for people the algal dividers should be processed before the eventual outcome is eaten. Different strategies, for example, treatment with lytic chemicals, high pressing factor homogenization, sonification and so forth, can be utilized 
for breaking the algal cell divider. Mycotoxins in certain contagious species, particularly Aspergillus parasiticus and A. flavus are known to create unfavorably susceptible responses, infections and liver malignant growth in people just as creatures. Consequently, it is a condition that mycotoxins are killed before contagious SCP is devoured. Utilization of bacterial SCP is restricted because of its significant expense. Collecting protein from microbes is exorbitant because of the more modest cell size. Shortage is the mind-boggling motivation behind why new protein sources should be looked for, as we can't keep on depending on the wasteful creation of creature proteins and plant related proteins. SCPs are another great protein source, appropriate for human and creature utilization. SCP items ought to be advocate in light of the fact that in resentment of bad-to-the-bone examination, SCPs are as yet not well known on moral grounds. Buyer opposition (in any event in created country markets) is extremely difficult to survive. Maintainability is another large issue in SCP creation that should be survive. SCP creation from byproducts would should be supplement rich, for example sufficient stock of nitrogen and phosphorus. There is an approaching around the world phosphate deficiency thus providing phosphates to the framework would not be an economical suggestion. The lack of supplements, particularly phosphorus presents the issue of supplement reusing, which likewise should be survived. All things being equal, SCPs seem as though they will assume a critical part later on for nourishment, on the off chance that we can promote the items and mollify fears about quality control.

\section{Review Analysis of Single cell Protein}

Human being is facing a major problem by the continuous increase in deficiency of proteins. Many underdeveloped countries like Algeria, Botswana, Nigeria, Madagascar and so on, are confronting significant food and nourishment lack issues. India, albeit a developing country, its significant populace is confronting nourishment lack and food shortage issues. Despite such overall issues, single cell proteins got from the waste natural items had been demonstrated a valuable innovation. Dried cells of microscopic organisms, green growth, yeast, and parasites, which contain high amount of protein and could be utilized as dietary enhancements, are called Single Cell Proteins (SCP). The current survey centers around utilization of an assortment of substrates for development of single cell protein. The different substrates which have been utilized as the normal material for the creation of different sorts of Single Cell Protein incorporates orange strip buildup, sweet orange buildup, sugarcane buildup, paper plant squander rice husk, wheat straw buildup, cassava squander, sugar beet mash, coconut squander, grape squander, mango squander, and so on Microbial protein or SCP has different advantages over creature and plant proteins in that its necessity for development are neither occasional or environment subordinate; it very well may be delivered all-round the year. It doesn't need a huge scope of land and it has high protein content with wide amino corrosive range, low fat substance and higher protein starch proportion than searches. It tends to be become on waste and it is ecological cordial as it helps in reusing waste. It is along these lines pointed toward auditing the creation and preparing of SCP from different substrates. Numerous contagious species are utilized as a wellspring of protein rich food (Bhalla et al, 2007). Numerous other filamentous species are additionally utilized as wellspring of single cell protein. In 1973, in second global gathering assembled at MIT, it was accounted for that Actinomycetes and filamentous organisms created protein from different substrates. During the world war II, preliminaries were made to use the way of life of Fusarium and Rhizopus (Yousuf, 2012) filled in maturation as a wellspring of protein food. The inoculums of Aspergillus oryzae (Anupama and Ravindra, 2000) or Rhizopus arrhizus were chosen due to their nontoxic nature. Saprophytic parasites develop on complex natural mixtures and convert them into straightforward constructions. High measure of contagious biomass is created because of development. Mycelia yield fluctuate enormously which relies on organic entities and substrates. Besides the wholesome advantages of single cell protein, another advantage of single cell protein innovation is their overtime creation. Additionally, it assumes its part in waste administration as waste materials are utilized as substrate. Little region of land is required and SCP is made in less time. Nutritive and food estimations of SCP shift with the microorganisms utilized. The strategy for gathering, drying and handling has an impact on the nutritive estimation of the completed item. Single cell protein fundamentally contains proteins, fats, sugars, debris fixings, water, and different components like phosphorus and Potassium. The structure relies on the life form and the substrate whereupon it develops. The high nucleic corrosive in SCP could be eliminated or decreased with one or the entirety of the following medicines: compound treatment with sodium hydroxide, treatment of cells with $10 \%$ sodium chloride, initiation of endogenous nucleases during conclusive phase of microbial biomass creation and warm stun. These strategies are pointed toward decreasing the ribonucleic corrosive substance from about $71 \%$ which is viewed as inside the satisfactory level. Huei-hsiung Yang in his investigation built up a straightforward strategy for decrease of nucleic corrosive in Brevibacterium NNJM98A by brooding of non-multiplying cells at $\mathrm{pH} 10.3$ and $55^{\circ} \mathrm{C}$ for 3 hours.

\section{Review analysis of production of single cell protein using Fungi from Sugarcane.}

Single cell protein is a protein removed from refined green growth, yeasts, or microorganisms and utilized as a substitute for protein-rich food sources, particularly in creature takes care of or as dietary enhancements. Numerous sorts of creature take care of contain single cell proteins. It can likewise be called biomass, bioprotein or microbial protein. The word single cell protein which was begat in the 1960 is viewed as fitting since the vast majority of the microorganisms develop as single or filamentous people. Other than its high protein content (around 60 - 82\% of dry cell weight), single cell protein likewise contains fats, sugars, nucleic acids, Vitamins and minerals. As indicated 
by different examinations on the maturations of organic product juices, it has been accounted for that they could be utilized as feed-stocks for the creation of single cell protein (SCP) in view of their degree of sugar and capacity to help the development of yeasts. Single cell proteins in this manner, are the dried cells of microorganisms, for example, yeast that could be filled in enormous scope culture frameworks for use as protein for human or creature utilization. The point of this examination was to research the chance of bioconversion of sugarcane extricate into single cell protein by utilizing contagious strain Aspergillus Niger. Trichoderma uses cellulose and pentose as a substrate for the production of single cell protein. good amount of reducing and non-reducing sugars (10.5 and $12.2 \%$, respectively) is found in the sugarcane extract, which is most favourable condition for the growth of microorganisms.

\section{Trichoderma reesei is used for the production of Single} cell protein in solid state fermentation

Single cell protein (SCP) has pulled in a great deal of consideration as an elective protein source to help the expanding request and to lessen the reliance on fishmeal in the creature feed and poultry enterprises. The SCP can be created utilizing lignocellulosic materials which are plentifully created persistently as horticultural deposits by Trichoderma reesei in strong state maturation framework. In this work, we assessed the impacts of different carbon sources (rice straw, corncob, bagasse, and espresso husk) which were joined with different nitrogen sources (Urea, Ammonium Sulphate, NPK) on SCP creation. The rice straw and espresso husk gave a higher SCP yield when joined with urea or NPK at $\mathrm{C} / \mathrm{N}$ proportion of 20:1furthermore, 30:1. The strong substrate which contained rice straw or espresso husk gave a higher SCP yield when joined with urea or NPK at C/N proportion of 20:1 and 30:1. The underlying dampness substance of the strong substrate gave a huge commitment to the SCP yield, the best return of SCP created in the substrate with the underlying water substance of $75 \%$. Then again, the proportion of inoculum size to the strong substrate of $1: 1(\mathrm{w} / \mathrm{v})$ gave the most extreme SCP yield. The impact of various carbon sources on SCP creation was assessed independently in strong substrate aging with urea compost was utilized as nitrogen source. The aging interaction condition was changed at temperature $30 \mathrm{C}, \mathrm{pH} 5$, dampness content $75 \%$, relative stickiness (RH) $95 \%$, and $\mathrm{C} / \mathrm{N}$ proportion of 20:1. All sort of strong substrates which have been tried having the option to be all around devoured by $T$. reesei and gave unrefined protein creation with an equivalent high rate (over 15\%). The measure of unrefined protein created by $\mathrm{T}$. reesei in strong substrate containing rice straw or espresso husk gave a better return, $22 \%$ and $21 \%$, individually. While in the bagasse or corncob strong substrate, the sum of unrefined protein created independently were $16 \%$ and $17 \%$.

\section{Conclusion:}

This research review's purpose is to help the reader understand different aspects posed by the research on the
Reviewing of major microbes as a Single Cell Protein. This is significant because it gives insights about Rhodobacter capsulatus, Lactobacillus acidophilus, Saccharomyces cerevisiae, Saccharomyces bulardii, Aspergillus niger, Spirulina, Chlorella, Trichoderma and Polysporous and their potential as a Single Cell Protein. There has been much research and discussion conducted on these opinions of them and their potential as Single Cell proteins. Most of the research found was on the potential of Rhodobacter capsulatus, Lactobacillus acidophilus, Saccharomyces cerevisiae, Saccharomyces boulardii, Spirulina, Chlorella, Trichoderma and Polysporous and their potential to produce single cell proteins from waste products such as wastewater, fruit peels, bagasse and fermentation waste products. This single cell protein can be used for reducing inflammation, combating hyperlipidaemia and showing anti-viral effects. Additionally, this review also shed light on the potential of single cell proteins, produced by organisms of the genus Saccharomyces, Aspergillus, Lactobacillus, Rhodobacter, Spirulina, Chlorella, Tricoderma and Polysporous. Research and testing are required to gain a better understanding of the role of major microbes as a single cell protein.

\section{Acknowledgement:}

We would like to thank our team Leader and supervisor/guide Bharat Kwatra, from Invenzion Labs Inc. and submentor Angarika Balakrishnan from Sunandan Divatia School of Science, whose expertise was invaluable in formulating the research questions, methodology and drawing conclusions. Their insightful feedback and guidance pushed us to sharpen our thinking and brought our work to a higher level.

\section{Human and animal rights}

No Animals/Humans were used for studies that are base of this research.

\section{Availability of data and materials}

The author confirms that the data supporting the findings of this research are available within the article.

\section{Funding acknowledgement and conflict of interest}

The authors whose names are listed immediately above certify that they have NO affiliations with or involvement in any organization or entity with any financial interest (such as honoraria; educational grants; participation in speakers' bureaus; membership, employment, consultancies, stock ownership, or other equity interest; and expert testimony or patent-licensing arrangements), or non-financial interest (such as personal or professional relationships, affiliations, knowledge or beliefs) in the subject matter or materials discussed in this manuscript.

\section{References}

1. Erdman, M. D., Bergen, W. G. \& Adinarayana Reddy, C. Amino acid profiles and presumptive nutritional assessment of single cell protein from certain lactobacilli. Appl. Environ. Microbiol. 33, 
(1977)

2. Kam, S., Kenari, A. A. \& Younesi, H. Production of single cell protein in stickwater by lactobacillus acidophilus and aspergillus niger. J. Aquat. Food Prod. Technol. 21, (2012).

3. Anjum, N. et al. Lactobacillus acidophilus: Characterization of the Species and Application in Food Production. Crit. Rev. Food Sci. Nutr. 54, (2014).

4. Saejung, C. \& Thammaratana, T. Biomass recovery during municipal wastewater treatment using photosynthetic bacteria and prospect of production of single cell protein for feedstuff. Environ. Technol. (United Kingdom) 37, (2016).

5. Garimella, S., Kudle, K. R., Kasoju, A. \& Merugu, R. Current Status on Single Cell Protein (SCP) Production from Photosynthetic Purple Non Sulphur Bacteria. J. Chem. Pharm. Sci. 10, (2017).

6. Spalvins, K., Ivanovs, K. \& Blumberga, D. Single cell protein production from waste biomass: Review of various agricultural by-products. Agron. Res. 16, (2018).

7. Spalvins, K., Zihare, L. \& Blumberga, D. Single cell protein production from waste biomass: Comparison of various industrial by-products. in Energy Procedia vol. 147 (2018).

8. Hülsen, T., Hsieh, K., Lu, Y., Tait, S. \& Batstone, D. J. Simultaneous treatment and single cell protein production from agri-industrial wastewaters using purple phototrophic bacteria or microalgae - A comparison. Bioresour. Technol. 254, 214-223 (2018).

9. Hülsen, T., Sander, E. M., Jensen, P. D. \& Batstone, D. J. Application of purple phototrophic bacteria in a biofilm photobioreactor for single cell protein production: Biofilm vs suspended growth. Water Res. 181, (2020).

10. Singh, A., Abidi, A. B., Agrawal, A. K. \& Darmwal, N. S. Single cell protein production by Aspergillus niger and its evaluation. Zentralbl. Mikrobiol. 146, 181-184 (1991).

11. Ravindra, P. BRAZILIAN ARCHIVES OF BIOLOGY AND TECHNOLOGY Studies on Production of Single Cell Protein by Aspergillus niger in Solid State Fermentation of Rice Bran. Brazilian Arch. Biol. Technol. 79, 79-88 (2001).

12. Bashir, A. \& Khan, I. Production of Single Cell Protein from Orange Peels Using Aspergillus niger and Saccharomyces cerevisiae.

doi:10.5829/idosi.gjbb.2014.9.1.82314.

(2014)

13. Suman, G., Nupur, M., Anuradha, S. \& Pradeep, B. Review Article Single Cell Protein Production: A Review. Int.J.Curr.Microbiol.App.Sci vol. 4 http://www.ijcmas.com (2015).

14. Haddish, K. Production of Single Cell Protein from Fruit of Beles (Opuntia Ficus-Indica L.) Peels Using Saccharomyces cerevisiae. J. Microbiol. Exp. 2, (2015).

15. Hezarjaribi, M., Ardestani, F. \& Ghorbani, H. R.
Single Cell Protein Production by Saccharomyces cerevisiae Using an Optimized Culture Medium Composition in a Batch Submerged Bioprocess. Appl. Biochem. Biotechnol. 179, 1336-1345 (2016).

16. Zafar, A. Production of Single Cell Protein from Saccharomyces cerevisiae by utilizing Fruit Wastes A STEP TO CONSERVATION View project M.phil View project. https://www.researchgate.net/publication/265350897 (2016).

17. Gervasi, T. et al. Production of single cell protein (SCP) from food and agricultural waste by using Saccharomyces cerevisiae. Nat. Prod. Res. 32, 648653 (2018).

18. Umesh, M., Thazeem, B. \& Preethi, K. Valorization of pineapple peels through single cell protein production using saccharomyces cerevisiae NCDC 364. Appl. Food Biotechnol. 6, 255-263 (2019).

19. Putra, M. D., Abasaeed, A. E. \& Al-Zahrani, S. M. Prospective production of fructose and single cell protein from date palm waste. Electron. $J$. Biotechnol. 48, 46-52 (2020).

20. Fabregas, J. \& Herrero, C. Marine microalgae as a potential (sop). Appl Microbiol Biotechnol vol. 23 (1985).

21. Fabregas, J., Herrero, C., Abalde, J. \& Cabezas, B. The marine microalga Chlorella stigmatophora as a potential source of single cell protein: enhancement of the protein content in response to nutrient enrichment. Journal of Industrial Microbiology vol. 1 (1986).

22. IA. Mahasneh. Production of single cell protein from five strains of the microalga Chlorella spp. (Clorophyta). Cytobiosis 90, 362-363 (1997).

23. RE Merchant, C. A. A review of recent clinical trials of the nutritional supplement Chlorella pyrenoidosa in the treatment of fibromyalgia, hypertension, and ulcerative colitis. Altern. Ther. Health Med. 3, 79-91 (2001).

24. Yamagishi, S., Nakamura, K. \& Inoue, H. Therapeutic potentials of unicellular green alga Chlorella in advanced glycation end product (AGE)related disorders. Med. Hypotheses 65, 953-955 (2005).

25. Sarma, A. P., Petar, P. \& Murthy, S. Spirulina as a Source of Single Cell Protein. vol. 21 (2008).

26. Deng, R. \& Chow, T. J. Hypolipidemic, antioxidant, and antiinflammatory activities of microalgae spirulina. Cardiovascular Therapeutics vol. 28 (2010).

27. Yunes Panahi et al. Investigation of the effects of Chlorella vulgaris supplementation in patients with non-alcoholic fatty liver disease: a randomized clinical trial. Hepatogastroentology 119, 2099-2103 (2012).

28. Panahi, Y. et al. Investigation of the effects of Chlorella vulgaris supplementation on the modulation of oxidative stress in apparently healthy smokers. Clin. Lab. 59, 579-587 (2013). 
29. Sotiroudis, T. G. \& Sotiroudis, G. T. Health aspects of Spirulina (Arthrospira) microalga food supplement. in Journal of the Serbian Chemical Society vol. 78 395-405 (Serbian Chemical Society, 2013).

30. Panahi, Y., Darvishi, B., Jowzi, N., Beiraghdar, F. \& Sahebkar, A. Chlorella vulgaris: A Multifunctional Dietary Supplement with Diverse Medicinal Properties. Curr. Pharm. Des. 22, (2015).

31. $\mathrm{Wu}, \mathrm{Q}$. et al. The antioxidant, immunomodulatory, and anti-inflammatory activities of Spirulina: an overview. Archives of Toxicology vol. 90 1817-1840 (2016).

32. SINGLE CELL PROTEIN AND BAKER'S YEAST PharmaTutor.

33. Single cell protein production and process. American Journal of food technology.

34. Single cell protein production by Trichoderma harzianum using waste banana peel. International Journal of Microbiological Research.

35. Kuhad, R. C. \& Singh, A. Lignocellulose Biotechnology: Current and Future Prospets. Crit. Rev. Biotechnol. 13, (1993).

36. Srividya, A. R., Vishnuvarthan, V. J., Murugappan, M. \& Dahake, G. Single Cell Protein-A Review. International Journal for Pharmaceutical Research
Scholars (2013).

37. Kant Bhatia, R., Nangul, A. \& Bhatia, R. Microorganism: A marvelous source of single cell protein Biotransformation of amides to Hydroxamic Acids View project Biotransformation for Industrialy important chemical View project MICROORGANISMS: A MARVELOUS SOURCE OF SINGLE CELL PROTEINS. Article in Journal of Microbiology vol.

2013

https://www.researchgate.net/publication/265592045 (2013).

38. Suman, G., Nupur, M., Anuradha, S. \& Pradeep, B. Review Article Single Cell Protein Production: A Review. Int.J.Curr.Microbiol.App.Sci vol. 4 http://www.ijcmas.com (2015).

39. Kumari, P. V. K., Rao, Y. S., Rama Vaishnavi, V. \& Sowjanya, D. PRODUCTION OF SINGLE CELL PROTEIN FROM SUGARCANE USING FUNGI. Int. J. Pharm. Sci. Res. 9, 1213 (2018).

40. Said, S. D., Zaki, M., Novita, E. \& Asnawi, T. M. Production of single cell protein by a local Trichoderma reesei in solid state fermentation: Effects of process variables. in Journal of Physics: Conference Series vol. 1376 (Institute of Physics Publishing, 2019). 